\title{
WestVirginiaUniversity
}

THE RESEARCH REPOSITORY @ WVU

Graduate Theses, Dissertations, and Problem Reports

2015

\section{Optimization of Pulsed-Vacuum Osmotic Dehydration of Blueberries}

Alexandra Marie Smith

Follow this and additional works at: https://researchrepository.wvu.edu/etd

\section{Recommended Citation}

Smith, Alexandra Marie, "Optimization of Pulsed-Vacuum Osmotic Dehydration of Blueberries" (2015). Graduate Theses, Dissertations, and Problem Reports. 6666.

https://researchrepository.wvu.edu/etd/6666

This Thesis is protected by copyright and/or related rights. It has been brought to you by the The Research Repository @ WVU with permission from the rights-holder(s). You are free to use this Thesis in any way that is permitted by the copyright and related rights legislation that applies to your use. For other uses you must obtain permission from the rights-holder(s) directly, unless additional rights are indicated by a Creative Commons license in the record and/ or on the work itself. This Thesis has been accepted for inclusion in WVU Graduate Theses, Dissertations, and Problem Reports collection by an authorized administrator of The Research Repository @ WVU. For more information, please contact researchrepository@mail.wvu.edu. 
Quality Indicators of Egg Sticks with added Omega-3 Fatty Acids and Lutein Under Different Packaging and Temperature Storage

\author{
Elizabeth Smith
}

Thesis submitted to the Davis College of Agriculture, Natural Resources and Design

at West Virginia University in partial fulfillment of the requirements for the degree of

\author{
Master of Science \\ in \\ Nutrition and Food Science \\ Jacek Jaczynski, Ph.D., Chair \\ Kristen Matak, Ph.D. \\ Melissa Marra, Ph.D, RD \\ Department of Animal and Nutritional Sciences \\ Morgantown, West Virginia \\ 2016
}

Keywords: Egg products, egg texture, egg color, flaxseed oil, fish oil, algae oil, food product development, $\omega-3$ polyunsaturated fatty acids, egg composition, storage quality and stability

Copyright 2016 Elizabeth Smith 


\begin{abstract}
Quality Indicators of Egg Sticks with added Omega-3 Fatty Acids and Lutein Under Different Packaging and Temperature Storage

Elizabeth Smith
\end{abstract}

Omega-3 enhanced egg sticks were developed by replacing egg yolk with $\omega-3$ rich salmon, algae, and flax oils. The eggs were fully cooked before analysis. Quality indicators for storage stability were measured throughout a 28-day period under different packaging and storage temperatures. Half of the egg sticks were vacuum packed, while the other half were aerobically covered with household plastic wrap. Further, eggs in both packaging groups were equally split into storage temperatures of $4^{\circ} \mathrm{C}$ and $10^{\circ} \mathrm{C}$, to mimic refrigeration and temperature abuse, respectively. Quality indicators were measured each week in all groups. Quality indicators included texture (TPA, Kramer shear), color $\left(\mathrm{L}^{*}, \mathrm{a}^{*}, \mathrm{~b}^{*}\right)$, lipid oxidation, fatty acid profile, proximate composition, physiological loss in weight, microbiological plate counts, and $\mathrm{pH}$. Egg sticks stored in vacuum packaging at $4^{\circ} \mathrm{C}$ had an overall slower degradation over time than all other treatments; however, vacuum packaged eggs did result in higher water loss, firmer texture, and higher anaerobic bacterial growth over storage time. 


\section{Acknowledgements}

I would first like to thank Dr. Jacek Jaczynski for encouraging me to explore unfamiliar topics in food and nutrition and for opening my eyes to the world of food science. I am thankful for the countless hours of support and patience that Dr. Jaczynski has so kindly offered.

I would also like to thank my committee members, Kristen Matak, PhD. and Melissa Marra, PhD. for providing endless guidance and going out of their way to answer my many questions. I would also like to thank Dr. Brett Kenney and Susan Slider for providing assistance and advice when needed.

I would like to give a special thanks to Sarah Beamer for all of her time and assistance. I could not have completed this project without her hard work, help, and moral support. 


\section{Table of Contents}

$\begin{array}{ll}\text { Contents } & \text { Page }\end{array}$

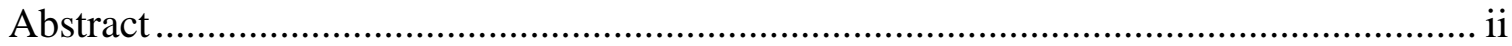

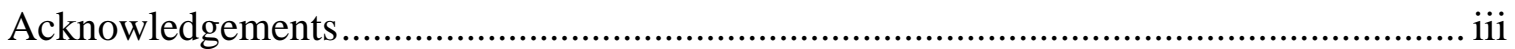

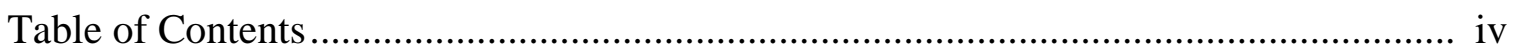

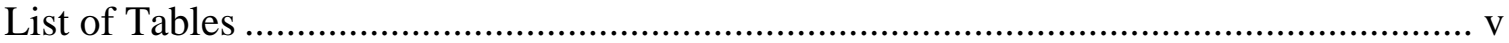

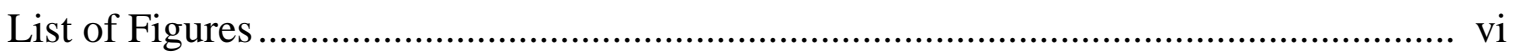

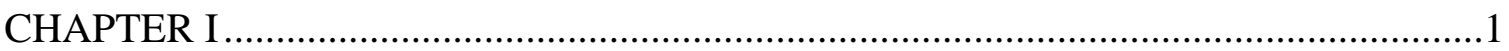

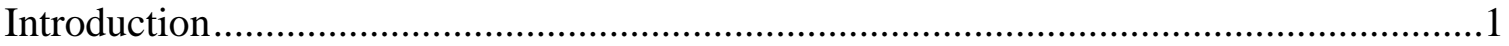

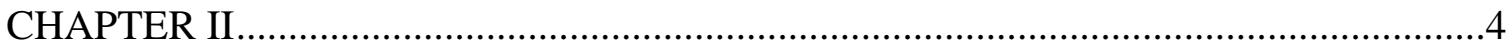

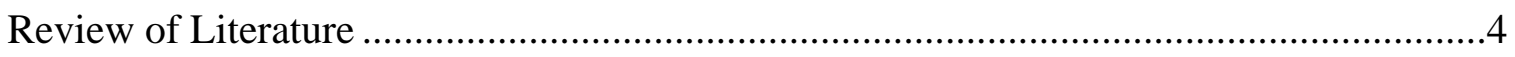

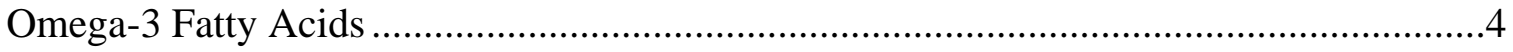

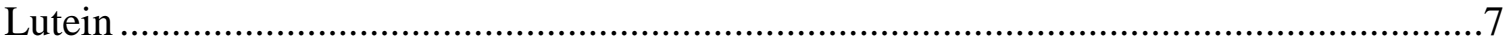

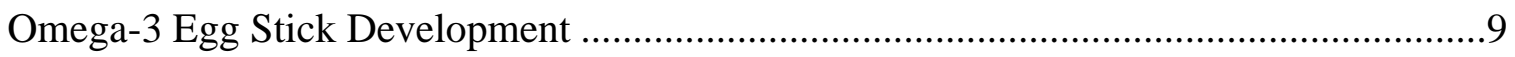

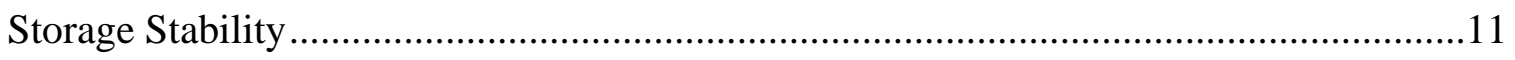

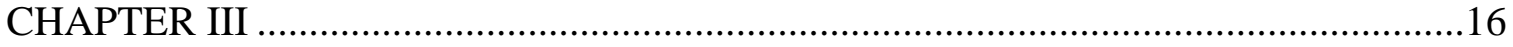

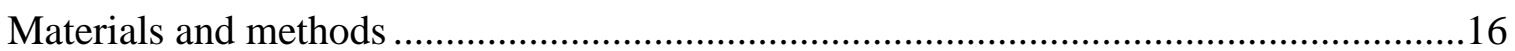

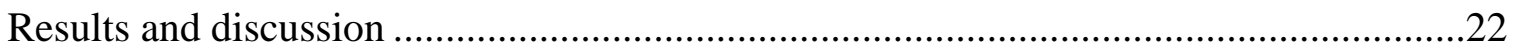

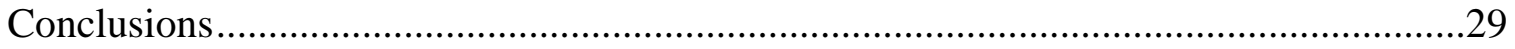

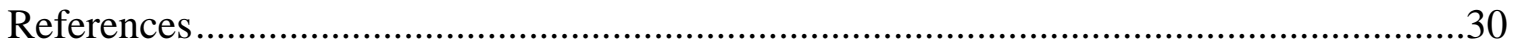




\section{List of Tables}

\section{Chapter III}

Table 1. Percent of physiological loss in weigh of cooked $\omega-3$ egg gels packaged under vacuum or aerobic wrap at $4^{\circ} \mathrm{C}$ and $10^{\circ} \mathrm{C}$ throughout a 28 -day period

Table 2. $\mathrm{pH}$ of cooked $\omega-3$ egg gels packaged under vacuum or aerobic wrap at $4^{\circ} \mathrm{C}$ and $10^{\circ} \mathrm{C}$ throughout a 28 -day period.

Table 3. Texture profile analysis (TPA) of cooked $\omega$-3 egg gels packaged under vacuum or aerobic wrap at $4^{\circ} \mathrm{C}$ and $10^{\circ} \mathrm{C}$ throughout a 28 -day period.

Table 4. Color analysis ${ }^{\mathrm{a}}\left(\mathrm{L}^{*}, \mathrm{a}^{*}, \mathrm{~b}^{*}\right)$ of cooked $\omega$-3 egg gels packaged under vacuum or aerobic wrap at $4^{\circ} \mathrm{C}$ and $10^{\circ} \mathrm{C}$ over a 28 -day period............................. 43

Table 5. Proximate composition ${ }^{\mathrm{a}}$ of cooked $\omega-3$ egg gels packaged under vacuum or aerobic wrap at $4^{\circ} \mathrm{C}$ and $10^{\circ} \mathrm{C}$ throughout a 28 -day period.

Table 6. Concentration of ALA, EPA, and DHA, omega-6/omega-3 fatty acids $(\omega-6 / \omega-$ 3 ), and unsaturated/saturated fatty acids (UFAs/SFAs) in cooked $\omega-3$ egg gels packaged

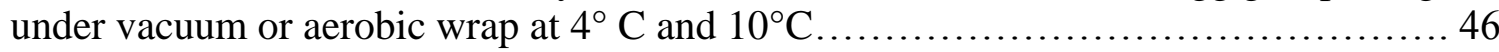

Table 7. Thiobarbituric reactive substances (TBARS) test as measured by $\mathrm{mg}$ malondialdehyde (MDA)/kg sample in cooked $\omega-3$ egg stick gels packaged under vacuum or aerobic wrap at $4^{\circ} \mathrm{C}$ and $10^{\circ} \mathrm{C}$ over a 28 day storage period. 


\section{List of Figures}

\section{Chapter III}

Figure 1. Kramer shear test of cooked $\omega-3$ egg stick gels packaged under vacuum or aerobic wrap at $4^{\circ} \mathrm{C}$ and $10^{\circ} \mathrm{C}$ over a 28 day storage period........................ 42

Figure 2. Microbiological analysis of cooked $\omega-3$ egg stick gels packaged under vacuum or aerobic wrap at $4^{\circ} \mathrm{C}$ and $10^{\circ} \mathrm{C}$ over a 28 day storage period. A) Total Plate Count, B) Anaerobic Plate Count, C) Psychrotrophic Plate Count.............................. 44 


\section{CHAPTER I}

\section{INTRODUCTION}

The functional food business is continually gaining popularity as consumers strive to find ways to gain additional health benefits from foods without making major dietary changes. By definition, functional foods are foods that provide health benefits in addition to the basic nutritional value that a food naturally provides (F Shahidi, 2004). Functional foods are created by the addition of vitamins, minerals or other bioactive substances, such as phytochemicals, antioxidants, or probiotics to foods. Increasing the nutritional value of conventional foods may be an effective method of increasing necessary nutrients that many diets are lacking. The intake of functional foods may provide an alternative therapeutic approach that could aid in the prevention or treatment of diet- related diseases (Magrone et al., 2013).

Extensive research has been done on the fortification of foods with omega-3 polyunsaturated fatty acids (PUFA) due to the large amount of evidence supporting the cardio-protective effects of these fatty acids. (DeFilippis et al., 2010). The typical American diet is especially low in omega-3 fatty acids and high in omega- 6 fatty acids (Lavie et al., 2009). This is a cause for concern due to the anti-inflammatory properties of omega-3 fatty acids and the pro-inflammatory properties of omega- 6 fatty acids. Increased inflammation can cause severe damage to the body while also contributing to disease (Mozaffarian \& Wu, 2011). An effective way to increase omega-3 fatty acids in the diet is through omega-3 enhanced functional foods. Popular staple foods are often used to create functional foods. The addition of $\omega-3$ fatty acids to eggs has become 
popular as a functional food due to the egg's low cost, high nutritional value, and functional versatility (F Shahidi, 2004). Omega-3 fatty acids are generally added to eggs through the incorporation of these fatty acids into chicken feed from sources such as flax seed, fish oil or algae oil into chicken feed (Baucells et al., 2000, Coorey et al., 2015).

In previous studies, Kassis et al. and Sedoski et al. developed a pre-cooked omega-3 egg stick that could be marketed as a convenience functional food. These egg sticks were made by removing the yolk and replacing it with $\omega-3$ fatty acid oils post laying (Kassis et al., 2010, Sedoski, 2011). The benefit of adding the oils post-laying is that it provides higher amounts of $\omega-3$ fatty acids per egg than most $\omega-3$ eggs (Kassis et al., 2010). This results in an amount that is more reflective of the daily recommendation. This method also replaces the saturated fats and cholesterol, which are abundant in the American diet, with the polyunsaturated fatty acids that many diets are lacking (Weech et al., 2014).

There is currently very little research looking at the effect of the addition of $\omega-3$ PUFAs post-laying on the shelf life of eggs. Like all perishable foods, egg quality traits decrease with increased storage time. The addition of $\omega-3$ fatty acid replaces the saturated fat in the yolk with polyunsaturated fatty acids, which are more susceptible to oxidation due to the degree of unsaturation and long length of their structures (Weech et al., 2014).

There are many changes that occur during prolonged storage including loss of water, increased albumin $\mathrm{pH}$, loss of $\mathrm{CO} 2$, and changes in color, flavor, and texture 
(Akteret al., 2014). Environmental factors that affect the storage stability of the egg over time include temperature, humidity, light exposure, and gaseous composition. Many researchers have studied the addition of antioxidants to omega-3 enriched foods as a method of slowing oxidative degradation (Fereidoon et al., 2010). In this study the carotenoid lutein was added as a natural coloring agent, which allowed the egg white to resemble a cooked whole-egg. Lutein possesses antioxidant and antimicrobial properties, which may be effective in delaying lipid oxidation. It is an important vitamin for eye health including reducing the risk of macular degeneration and cataracts (Dawczynski et al., 2013, Richer et al., 2004). Research has also shown it to have positive effects on cardiovascular related events (Wang et al., 2013). The addition of lutein to the $\omega-3$ egg is three-fold as it may extend the shelf life of the product while offering additional health benefits to the consumer and providing the egg with its yellow color.

Several studies examined the storage stability of hard cooked eggs under different packaging and temperature storage (Oblinger et al., 1974, Akter et al., 2014, Botsoglou et al., 2012)(Mozaffarian \& Wu, 2011). The majority of this research has focused on prolonging shelf life of hard-cooked eggs through use of pickling solutions or acidic coatings in addition to packaging. To our knowledge, no other studies have looked at the storage stability of cooked egg whites with added $\omega-3$ fatty acids. The aim of this study is to evaluate the storage stability of $\omega-3$ egg sticks under commonly used packaging and storage temperature conditions throughout a 28-day period. 


\section{Chapter II}

\section{REVIEW OF LITERATURE}

\section{Omega-3 Fatty Acids}

Many health benefits have been associated with the omega-3 fatty acid consumption in both clinical interventions and observational studies (Mozaffarian \& Wu, 2011). The most significant impact of these fatty acids known is their impact on primary and secondary prevention of cardiovascular disease (CVD) et al., 2002). Long-chain $\omega-3$ fatty acids, docosahexanoic acid (DHA) and eicosapentanoic acid (EPA), have shown to have the most significant effect on reducing risk factors related to CVD through their impact on factors related to inflammation (Kris-Etherton et al., 2002). EPA and DHA can be synthesized endogenously by humans from alpha-linolenic acid (ALA). ALA is an essential $\omega-3$ fatty acid that can be converted to DHA and then to EPA through a process involving the desaturation and elongation of the fatty acid, resulting in the conversion of the short chain fatty acid, ALA, to long chain fatty acids, DHA and EPA. This conversion is not very efficient; therefore, it is necessary to incorporate these fatty acids into the diet. Endogenous conversion of ALA to EPA is approximately $8 \%$ and conversion to DHA is approximately $0-4 \%$. There are multiple factors that can influence the efficiency of the conversion of ALA to EPA and DHA. One factor is the competitive inhibition, which occurs as a result of the competition between omega-3 fatty acid, ALA and omega- 6 fatty acid, linoleic acid (LA) for the enzymes, desaturase and elongase. These enzymes are essential for the desaturation and elongation that converts ALA to EPA and DHA. EPA synthesis is reduced by the presence of high amounts of LA because of the competitive inhibition (Kris-Etherton et al., 2002, Mozaffarian \& Wu, 
2011, Kris-Etherton et al., 2009, Goyens et al., 2006). Synthesis of EPA and DHA can be improved by increasing consumption of ALA or by decreasing intake of LA (Goyens et al., 2006).

According to Simopoulos et al, the ideal ratio of omega- $6 / 3$ in the diet ranges from 1:1 to 5:1. The typical Western diet contains a ratio of $15: 1$ to $50: 1$, indicating that omega- 6 consumption is much higher than $\omega-3$ consumption (Simopoulos, 2002). The increase of omega- 6 consumption in the U.S. is related to increased use of vegetable oils in cooking and increased addition of these oils to processed foods (Blasbalg,et al., 2011). There is no current recommendation for the consumption of omega-3 fatty acids; however, several federal and scientific health agencies have made recommendations regarding omega-3 fatty acid intake for the treatment and prevention of cardiovascular related diseases. The American Heart Association recommends that adults should consume approximately $500 \mathrm{mg} / \mathrm{d}$ of EPA + DHA or two 4-oz servings of fish per week. Recommendations for ALA are $1.6 \mathrm{~g} / \mathrm{d}$ for men and $1.1 \mathrm{~g} / \mathrm{d}$ for women according to the Institute of Medicine of the National Academies (Wallet al., 2010, Artham et al., 2008, Lavie et al., 2009, Kris-Etherton, et al, 2009, Goyens et al., 2006, Simopoulos, 2002). Intake of DHA and EPA are commonly low in the American diet (Simopoulos, 2002). According to the National Health and Nutrition Examination Survey (NHANES), "the median intake of ALA is less than 1g/d and the median intake of EPA + DHA is zero" (Papanikolaou et al., 2014).

Many of the omega- 6 fatty acids consumed in the American diet are essential; however, consuming these in large quantities, while also consuming omega-3 fatty acids in low quantities can result in adverse health effects. Eicosanoids are bioactive molecules 
derived from $\omega-3$ and 6 fatty acids. They are important contributors in the initiation or reduction of inflammation, platelet aggregation, thrombosis, arrhythmias, blood pressure, and hypertriglyceridemia (Blasbalg et al., 2011, Simopoulos, 2002). These eicosanoids include leukotrines, prostaglandins, and thromboxanes. (Mozaffarian \& Wu, 2011). $\omega-3$ fatty acids provide anti-inflamatory properties while $\omega-6$ fatty acids deliver an inflammatory response. A diet high in $\omega-6$ fatty acids has been shown to be prothrombotic and proaggregatory while also increasing vasospasm and vasoconstriction (Papanikolaou et al., 2014, Kris-Etherton et al., 2002). These negative responses can be decreased by reducing consumption of $\omega-6$ fatty acids or increasing the amount of $\omega-3$ fatty acids in the diet. $\omega-3$ fatty acids are found in many foods, which can be added to the diet to increase $\omega-3$ consumption. Food sources high in $\omega-3$ fatty acids include fatty fish such as salmon, sardines, and mackerel, algae, nuts, and seeds, including walnuts, flaxseeds, and chia seeds (He, 2009, Papanikolaou et al., 2014). $\Omega-3$ fatty acids can also be incorporated into the diet by consumption of foods enriched or fortified with $\omega-3$ fatty acids. In the current study, $\omega-3$ fatty acids are incorporated into the egg stick through the addition of salmon, flaxseed, and algae oils to the product. The amount of $\omega-3$ oils added to the egg sticks in this study provides approximately $1 \mathrm{~g}$ ALA and $0.7 \mathrm{~g}$ EPA + DHA per egg stick. This is the highest achievable level that could be added to the eggs without imparting a fishy flavor. Consuming only one egg stick per day provides the suggested dose of $\omega-3$ fatty acids per day.

In the previous studies and the current study, the egg stick was formulated without the incorporation of the yolk, which eliminates the saturated fats naturally found in the egg. A variety of fats are required in the diet for optimal health including saturated fats 
when eaten in moderation(Weech et al., 2014). The 2015-2020 Dietary guidelines for Americans recommends consuming less than $10 \%$ of calories per day from saturated fats. The daily intake of saturated fat in the United States is around 11 percent or higher ("Dietary Guidelines for Americans. 8th Edition.," 2015). For adults who suffer from some form of CVD, the American Heart Association recommends reducing saturated fat to no more than 5 to 6 percent of total calories per day ("The American Heart Association," 2016). Dietary fat is essential for normal body function; however, overconsumption of fat, like any macronutrient can lead to fat storage, which ultimately leads to weight gain. Overconsumption of saturated fats in particular are associated with increase in levels of LDL cholesterol in the blood, which may contribute to an increased risk or heart disease or stroke; however, this topic is controversial (Dias et al., 2014). A systematic review by Weech et al suggested that lowering dietary saturated fat intake and replacing it with mono or polyunsaturated fat, such as $\omega-3$ fatty acids, could potentially reduce CVD events by $14 \%$ by improving lipid profile (Weech et al., 2014). Incorporating the $\omega-3$ egg stick into the diet could be a convenient method of replacing saturated fats with PUFAs. This product could be especially beneficial to at risk groups, such as those with CVD.

\section{Lutein}

Lutein is a fat-soluble vitamin and a member of the carotenoid family and is considered to be a xanthophyll. It is most commonly found in dark pigmented plant based foods, such as dark leafy vegetables and brassica vegetables. Lutein is found naturally in egg yolks and is what provides the yellow pigmentation (Wang et al., 2013). A typical egg contains 0.3-0.5 mg xanthophylls. Lutein comprises over half of these xanthophylls 
present in the yolk (Leeson \& Caston, 2004). Addition of lutein to egg white in this current study gives the appearance of a cooked whole egg. The poultry industry has used carotinoids in order to enrich pigmentation of the egg yolk through addition of lutein to chicken feed (Leeson \& Caston, 2004). In addition to adding a yellow pigment, lutein may have health benefits due to its high antioxidant properties. A variety of plant products have been used as food preservatives in order to delay food spoilage (Fereidoon et al., 2010). A study by Chung et al, showed that consumption of lutein from supplements, green leafy vegetables, and eggs increased serum lutein levels; however, the bioavailability of lutein when incorporated in eggs was higher than that from supplements and leafy vegetables. This is likely because the lutein is fat-soluble and the egg contains fat. (Chung et al., 2004).

Much research has focused on the roles that lutein plays in eye health. It has been shown to improve visual function, while also aiding in prevention and slowing the progression of macular degeneration. A study by Wang et al. saw significant reduction of C-reactive protein when subjects were supplemented with 10 or 20 mg lutein throughout a 12-week period. A significant correlation was found between the increase in plasma lutein and decrease in C-reactive protein (Wang et al., 2013). Several studies have linked high concentrations of C-reactive protein with increased risk of cardiovascular events. This suggests that lutein supplementation might decrease inflammatory responses, which could decrease risks associated with CVD (Wang et al., 2013). Like lutein, DHA is also found in the retina, and has been noted for its importance in visual development. Research suggests that the combination of lutein and DHA may work synergistically to protect against advanced macular degeneration (AMD) (Chung et al., 2004). According 
to the American Macular Degeneration Foundation (AMDF), the therapeutic dose of lutein in the diet is approximately $6 \mathrm{mg} /$ day or higher; however Rosenthal et al. saw some improvements in visual field at supplemental doses as low as $2.5 \mathrm{mg} /$ day (Rosenthal et al., 2006). The omega-3 egg stick in this current study contains lutein at a concentration of $1.5 \mathrm{mg}$ per egg stick. Consumption of four egg sticks per day would provide the recommended $6 \mathrm{mg}$ of lutein per day suggested as a therapeutic dose. The Age Related Eye Disease Study (AREDS) reported that consistent intake of lutein, $\omega-3$ fatty acids, or a combination of the two decrease the risk of developing AMD since they both play crucial roles in eye function. (Age-Related Eye Disease Study 2 Research Group, 2013). Some research involving AMD patients report benefits of lutein and $\omega-3$ fatty acids including improved visual acuity, contrast sensitivity. (Dawczynski et al., 2013). A study by Tokusoglu looked at the addition of lutein to cream cheese. Luteintreated cheeses showed lower syneresis compared to cheese without lutein. This may be because lutein is hydrophobic and cream cheese contains whey. It also showed that total aerobic plate count was significantly higher in cheeses not treated with lutein. These results were found at concentrations of 1.5 and $3.0 \mathrm{mg}$ lutein per $100 \mathrm{~g}$ cheese (Tokuşoğlu, 2013). These results indicate that lutein may have antimicrobial, antioxidant properties, which could be beneficial in slowing degradation in foods caused by prolonged storage.

\section{Omega-3 egg stick development}

Eggs are sold in many forms to suite consumers' needs. In addition to raw eggs, grocery stores now offer hard-boiled eggs, egg whites, and altered egg products, such as 
eggbeaters (Shahidi, 2004). In a previous study, Kassis et al developed the original egg stick with added omega-3 fatty acids from flaxseed, krill, menhaden, or algae oils (N. Kassis et al., 2010). The egg yolk was removed in order to eliminate saturated fat and cholesterol and omega-3 fatty acids were added to replace the fat in the yolk. In this study, the nutritional composition of the egg stick was evaluated. This was done by examining the amino acid profile, mineral profile, as well as cholesterol and omega-3 fatty acid content. This product was also compared to the compositions of cooked wholeegg and a liquid egg product. They found that the proximate composition of the omega-3 egg stick matched that of the whole-egg, which was the original intention of the formulation. Creating the egg stick to have a similar proximate composition to a whole egg ensures that the omega-egg stick will have similar texture, mouth feel, and flavor to the whole egg. The amino acid profile for the egg stick was found to be comparable to the whole egg $(\mathrm{P}<0.05)$. They also discovered that the egg stick included higher levels of methionine, phenylalanine, and valine than the whole egg. This could be due to the addition of powered egg whites to the egg stick. They proposed that the egg stick might be a more nutritive option than the egg substitute, as the egg stick composition more closely matched that of the whole egg and also included the added benefits of the $\omega-3$ fatty acids (N. Kassis et al., 2010). Another study was conducted with the $\omega-3$ egg sticks by Sedoski et al, which evaluated the shelf life of the egg sticks when vacuum packed and stored at $4{ }^{\circ} \mathrm{C}$ for a 14 day period. Degradation of the egg stick was determined by measurement and analysis of TBARS, pH, color, water loss, TPA, microbial analysis. It was found that there were no significant changes in $\mathrm{pH}$, color, loss of water, TBARS, or texture. Microbial analysis specifically monitored for salmonella spp and none was 
detected. This study also evaluated sensory components of the egg. A panel of 56 adults was recruited for a sensory evaluation. Panelists were randomly given 4 samples and were asked to rate each sample on a 9-point hedonic scale where $1=$ dislike extremely and $9=$ like extremely. They were asked to evaluate odor, visual color, texture between fingers, flavor, mouth feel, and overall liking of each sample. The results showed that the color of the experimental egg sticks was rated more favorably than that of the whole egg, confirming that panelists preferred eggs with a darker yellow color. When rating odor, texture between fingers, and mouth feel, panelists seemed to prefer the whole egg to the egg stick, but this preference was not shown to be significant. No significant differences were seen between the egg stick and whole egg for ratings of flavor or overall liking. These results showed that the egg stick was generally well liked and furthermore, $89 \%$ of panelists showed interest in purchasing a similar product in the future (Sedoski, 2011).

\section{Storage Stability}

To the consumer, shelf life is the length of time that a food can be kept before it is considered unsuitable for consumption. This is usually determined by the consumer's perception of acceptable quality. The point at which a consumer rejects a food based on quality deterioration is generally considered the shelf life. In many cases, the quality of the food is already considered unacceptable by the consumer before the food becomes microbiologically unsafe and is considered dangerous for human consumption (Kilcast \& Subramaniam, 2011). There are many factors that affect the storage stability of a food product. The deterioration and spoilage of food is caused by chemical, biochemical, and physical changes. These changes include lipid and protein oxidation, moisture loss, change in $\mathrm{pH}$, altered texture and flavor, off-odors, change in color, and loss of nutrients. 
Common environmental factors that affect these changes include oxygen presence, temperature, water content, and pH (Hayes et al., 2011, Kilcast \& Subramaniam, 2011, Gray et al., 1996).

There are many different chemical and physical changes that take place throughout prolonged storage. These changes can be slowed with the addition of proper storage including packaging and control of environmental factors such as temperature, and gas composition/exposure. The nutrient content of the egg albumin is largely made up of protein and water. This composition is ideal for bacterial growth, giving the unshelled egg a short shelf life (Akter et al., 2014). The USDA-recommended storage conditions for household hard cooked eggs is 1 week under refrigeration at $4-5^{\circ} \mathrm{C}$ ("The U.S. Department of Agriculture Food Safety and Inspection Service," 2016). Temperature is one of the most important environmental factors that affect the rate of chemical and physical deterioration in food. Proper refrigeration storage of eggs at $4^{\circ} \mathrm{C}$ helps to delay deterioration by decreasing enzymatic and microbial growth, resulting in maintained quality(Kilcast \& Subramaniam, 2011). Temperature also contributes to rate of oxidation.

Access to oxygen is another contributor to deterioration, as it accelerates oxidation. Lipid oxidation results in the development of rancidity. Over-wrapped packaging systems are not as susceptible to the build-up of volatile off-odor-causing products as permeable allow these volatiles to leave the package. Lipid oxidation greatly contributes to quality deterioration in foods and is especially prominent in meat products. This oxidation process results in adverse changes in flavor, color, texture nutritive value, and eventually degradation of proteins. The build-up of volatile, off-odor causing products in 
packaging will eventually cause meat to become inedible and rancid. Extent of lipid oxidation is decided through measurement of the accumulation of thiobarbituric acid reactive substances (TBARS) in foods (Love \& Pearson, 1971, Kraliket al., 2014). The oxidation of lipids is often linked to the degradation of proteins. This occurs when reactive oxygen species produced during lipid oxidation begin to oxidize proteins.

Proteins also degrade throughout storage by means of enzyme activity such as proteolysis, which causes hydrolysis of amino acid peptide bonds, shortening protein chains(Love \& Pearson, 1971, Kilcast \& Subramaniam, 2011). Protein degradation can result in loss of enzyme activity, amino acid destruction, loss of color, and change in texture and moisture content. Protein degradation is also highly affected by $\mathrm{pH}$, which plays a role in protein function and solubility(Kilcast \& Subramaniam, 2011).

The $\mathrm{pH}$ of food is also directly correlated with moisture loss, color stability, and microbial growth. $\mathrm{pH}$ contributes to moisture loss during storage, known as syneresis. Syneresis can also be affected by temperature, but is most directly affected by $\mathrm{pH}(\mathrm{Kralik}$ et al., 2014). Foods with a high $\mathrm{pH}$ tend to favor water retention more so than those of low $\mathrm{pH}$. A study by Kralik et al., looking at storage of eggs found that albumin $\mathrm{pH}$ increased significantly throughout a 28-day storage period(Kralik et al., 2014). pH has also been shown to have a negative impact on color. Lutein, the coloring agent used in the present study, is a carotenoid. According to et al. the color of carotenoid compounds can degrade under low pH conditions. Color can also be affected by light and access to oxygen(Kilcast \& Subramaniam, 2011).

Microbial growth in foods is also largely impacted by $\mathrm{pH}$. Huxsoll et al. found that foods with a lower $\mathrm{pH}$ resulted in lower microbial growth of spoilage bacteria than those with a 
high $\mathrm{pH}$, giving high $\mathrm{pH}$ foods a longer shelf life (Huxsoll \& Bolin 1989). Many different bacteria are found to grow on eggs. Salmonella is a serious concern in poultry derived foods. It is the main pathogenic bacteria related to foodborne illness from egg consumption. Most ready to eat egg products undergo heat-treatments that reduce bacterial growth, whether it be cooking the egg to an appropriate temperature or pasteurization, which will eradicate salmonella. Pasteurization consists of bringing the egg to $140^{\circ} \mathrm{F}$ and keeping it at that temperature for three and a half minutes (Jan et al., 2011, Salfinger \& Tortorell, 2015). Bacteria that are heat-resistant, including bacillus cereus may still grow after heat treatments. A common concern in the storage of perishable foods is the growth of psychrotrophic bacteria, which survive heat treatment. These bacteria are able to grow at refrigeration temperatures of $0-7^{\circ} \mathrm{C}$ (Jan et al., 2011, Jan \& Baron, 2015). Many strains of this group produce toxins in food or the human intestine that can cause severe gastrointestinal dysfunction (Lorenzo et al., 2012, Ercolini et al., 2009). Psychrotrophic bacteria also greatly contribute to food spoilage, resulting in adverse organoleptic changes (Ercolini et al., 2009).

There are many methods used to extend shelf life of foods. As mentioned before, proper refrigeration of foods is one of the most important factors affecting the shelf life of foods (Ercolini et al., 2009). The method in which a food is packaged will also greatly affect the rate of deterioration. Food packaging systems commonly used in food production include vacuum packaging and modified atmospheric packaging (MAP). Vacuum packaging reduces the amount of oxygen available to the packaged food. MAP is similar to vacuum packaging, but with the advantage of having control of the gas composition in the bag. A combination of carbon dioxide, nitrogen, and oxygen are used 
in order to create an environment that facilitates a longer shelf life for the food (Lorenzo et al., 2012, Hur et al., 2013). In a study by Lorenzo et al., a comparison of vacuum pack, aerobic over-wrap, and MAP was conducted in the storage of fresh foal meat. Findings showed that vacuum packaging was the most effective at reducing microbial spoilage, maintaining color, and increasing lipid and protein stability. The MAP treatment reduced microbial growth and lipid oxidation, however the sensorial qualities, color, and carbonyl content were similar to that of the meat in the aerobic over-wrap, which was least affective in slowing degradation (Lorenzo \& Gómez, 2012).

Addition of antioxidants has also been shown to stabilize food lipids resulting in decreased oxidative damage over storage time. Some common plant-based antioxidants that are used in food preservation include tocopherols/tocotrienols, ascorbic acid, carotenoids, and polyphenols (Tokuşoğlu, 2013, Fereidoon et al., 2010). In the present study, a carotenoid is used as a coloring agent, which also may double as an antioxidant to decrease oxidative damage. A study by Ripoll et al. compared the shelf life of lamb packaged with vitamin $\mathrm{E}$ to a control of lamb without vitamin $\mathrm{E}$. They found that lamb packaged with vitamin E had much lower TBARS values, lipid oxidation completely stopped, and color better was maintained (Ripoll et al., 2011). 


\section{CHAPTER III}

\section{MATERIALS AND METHODS}

\section{Product Formulation and Treatments}

The composition of the $\omega-3$ egg stick was based on the formulation created by Kassis, et al. and Sedoski et al. This egg formulation was created to mimic the proximate composition of a cooked, whole egg in order to provide similar sensory, textural, and flavor qualities (Kassis et al., 2010, 2012, Sedoski, 2011). The final egg recipe used in this study was formulated after conducting multiple cooking trials. Kroger brand grade A, large eggs were purchased and used in this experiment. All eggs were cooked using the same formulation. The egg formulation used in this study was as follows:

1) $430 \mathrm{ml}$ fresh egg whites

2) $50 \mathrm{ml} \omega-3$ rich oils

3) $15 \mathrm{~g}$ freeze dried egg whites from Honeyville Inc. (Bringham City, UT).

4) 5 g non-iodized salt $(\mathrm{NaCl})$

5) $2.5 \mathrm{ml}$ lecithin

6) $0.3 \mathrm{~g}$ cold water dispersible lutein from ZMC-USA (The Woodlands, TX), dissolved in $5 \mathrm{ml}$ water

A combination of $\omega-3$ fatty acid oils were used in order to provide a mixture of ALA, DHA and EPA in the eggs. This mixture was intended to closely reflect the recommended daily intake for ALA, DHA, and EPA for adults. The oil composition added resulted in $1.12 \mathrm{~g}$ ALA, and $0.7 \mathrm{~g}$ EPA + DHA per egg stick. The following $\omega-3$ oils were incorporated in the formulation: 
1) Flaxseed oil from Jedwards International Inc. (Quincy, MA).

2) Algae oil from Source, LLC (Chapel Hill, NC).

3) Salmon oil from Jedwards International Inc. (Quincy, MA).

$15 \mathrm{~g}$ freeze-dried egg whites were rehydrated in $15 \mathrm{ml}$ of warm water approximately 18 hours prior to the mixing of all other ingredients to ensure proper rehydration. After this period of time, all ingredients except lutein were combined in a $1 \mathrm{~L}$ beaker. A preliminary study was conducted to determine how much lutein was needed to match the color of a whole egg. A whole egg was cracked into another beaker and scrambled with a whisk. This was used as a reference for color of a whole egg. Water-soluble lutein was dissolved in $5 \mathrm{ml}$ water and was then slowly added into the egg mixture until the color matched the whole egg reference. The mixture was then placed on a stir plate (Thermix Stirring Hot Plate Model 310T, Fisher Scientific, Fairlawn, NJ) with a 3-inch magnetic stir bar. The mixture was stirred for 1 hour at a speed of 5. This method of mixing was used in previous experiments and resulted in uniform egg gel.

The egg mixture was next poured into polycarbonate tubes (length $=18 \mathrm{~cm}$, internal diameter $=1.90 \mathrm{~cm}$, wall thickness $=0.635 \mathrm{~cm}$ ) that were coated with cooking spray (Kroger brand canola cooking spray, Kroger Co., Cincinnati, OH) and then sealed with standard O-rings. The polycarbonate tubes were then placed into a pot of boiling water for a 10-minute period. Egg sticks were cooked in batches of 10. They were then taken from the boiling water and placed into an ice bath for 5 minutes in order to stop the cooking process. Eggs were vacuum packed and refrigerated overnight at $4^{\circ} \mathrm{C}$ to ensure proper gel formation. 
A total of 150 egg sticks were made from three large batches of egg mixture. The eggs were divided into four treatment groups. Eggs were divided into groups of three to be packaged and each group contained one egg gel from each of the three batches prepared. Each package was prepared by placing three egg sticks onto a polystyrene tray which was then aerobically wrapped with household kitchen plastic wrap (Glad® Clingwrap) or inserted into vacuum bags (10 by $20 \mathrm{~cm}, 3 \mathrm{mil} \mathrm{st} \mathrm{barrier,} \mathrm{Nylon/PE}$ vacuum pouch, Kock, Kansas City, MO) and vacuum packed. Further, the eggs from each packaging treatment were equally divided into two temperature treatments of $4^{\circ} \mathrm{C}$ and $10^{\circ}$ to mimic refrigeration and temperature abuse, respectively. The eggs were stored for a four-week period (28 days). Samples from each group were removed and analyzed once per week on days $0,7,14,21$, and 28 days of storage in order record degradation throughout shelf life.

\section{Analytical Procedures}

Physiological weight loss: The weight of the packaging with and without egg gels was determined on day 0 and again after each period of storage in order to detect weight loss due to packaging and storage conditions, as well as loss over time. Weight losses were expressed as a physiological loss in weight (PLW) as a percentage of the initial sample weight using the equation:

$$
\operatorname{PLW}(\%)=\underline{\text { initial weight }- \text { final weight }} \times 100 \mathrm{~g} \text { sample }
$$

$$
\text { Initial weight }
$$

pH analysis: $\mathrm{pH}$ of the egg gels was determined using a digital $\mathrm{pH}$ meter (Hanna Instruments HI 99163 Meat $\mathrm{pH}$ meter) To measure the $\mathrm{pH}$ of the egg gels, the $\mathrm{pH}$ meter 
was directly inserted into the gel. $\mathrm{pH}$ of egg gels was taken at the end of each week for the four-week period.

Texture analysis: Texture of the cooked gels was determined using Kramer shear test and texture profile analysis (TPA). Each sample was run in triplicate. Gels were left at room temperature for two hours prior to texture analysis in order to be tested at the same temperature. Kramer shear test was run using a texture analyzer (Model TAHDi, Texture Technologies, Scarsdale, NY) with a Kramer shear cell attachment tool. Each gel was measured and cut to an $8.0 \mathrm{~cm}$ length and then weighed. Shear force was measured at $127 \mathrm{~mm} / \mathrm{min}$ crosshead speed and expressed as maximum peak force (g peak force/g of gel sample) (Chen, Beamer and Jaczynski, 2009). Texture profile analysis (TPA) of the gels was performed using a texture analyzer (model TA_HDi, Texture Technologies, Scarsdale, NY) using a 50kg load cell. The gels were compressed using a two-cycle compression force verses time program. Stable Micro Systems Software was used to compute data. Samples were compressed to $50 \%$ using a $70 \mathrm{~mm}$ TPA compression plate attachment with a preset speed of $127 \mathrm{~mm} / \mathrm{min}$. TPA was used to determine hardness, adhesiveness, springiness, and chewiness of egg gels.

Color measurements: Changes in surface color of each egg gel was measured over time using a Minolta Chroma Meter CR-300 colorimeter. The instrument was calibrated using a white reference tile No. 21333180 (CIE L 93.1; $a^{*} 0.3135 ; b^{*} 0.3198$ ) before color measurements were taken. The $\mathrm{L}^{*}, \mathrm{a}^{*}$, and $\mathrm{b}^{*}$ color measurements were determined using the CIELAB color space. The value for $\mathrm{L}^{*}$ represents lightness, $\mathrm{a}^{*}$ represents red/green, and $b^{*}$ represents yellow/blue chromaticity. 
Microbiological analysis: Aerobic, anaerobic, and psychotropic plate counts were determined using spread plate method ( Ten grams of egg were weighed and aseptically placed in a stomacher bag with $90 \mathrm{ml}$ of sterile $0.1 \%$ peptone buffer solution (butterfields). This was mixed in ( machine) for 2 minutes. Serial dilutions were made in PBS and then inoculated onto sterile petri plates of tryptic soy agar. $1 \mathrm{ml}$ of each dilution was plated in triplicate. Aerobic plate counts were spread plated and incubated at $35^{\circ} \mathrm{C}$ for 48 hours. The same method was used for anaerobic plate counts except these were first placed in an anaerobic chamber before incubation. Psychotrophic bacteria were spread plated and incubated at $4^{\circ} \mathrm{C}$ for 10 days. Following incubation, plates containing 30-300 colonies were counted. Colonies were measured as long colony-forming units (CFU) per egg.

Proximate composition: Proximate composition including total fat, crude protein, ash, and moisture content were determined for the cooked gel samples. Total fat content was determined using the Soxhlet extraction method (AOAC, 1995) and was expressed as g/100 g (dry weight basis). Crude protein was determined using Kjeldahl assay (AOAC, 1995) and was expressed as $\mathrm{g} / 100 \mathrm{~g}$ (dry weight basis). Ash content was determined by incinerating samples in a muffle furnace at $550^{\circ} \mathrm{C}$ for $24 \mathrm{~h}(\mathrm{AOAC}$, 1995). Moisture content was determined by placing $2 \mathrm{~g}$ of each egg sample into an aluminum dish in a drying oven at $105^{\circ} \mathrm{C}$ for $24 \mathrm{~h}$ (AOAC, 1995).

Fatty acid profile: Fatty acid profile was determined for the cooked gel samples according to AOAC methods 965.49 and 996.06 .17 . Lipids were extracted by acid hydrolysis into ether and methylated to fatty acid methyl esters, which were measured quantitively by using a capillary gas-liquid chromatograph (GLC) (Model 7890A 
equipped with a 7683B series injector standard (triundecanoin, C11:0). Helium was used as the carrier gas with a $0.75 \mathrm{~mL} \min -1$ flow rate and a $200: 1$ split ratio. The initial temperature of $100^{\circ} \mathrm{C}$ was held for $4 \mathrm{~min}$ and then increased to the final temperature of $240^{\circ} \mathrm{C}$ at a heating ramp of $3^{\circ} \mathrm{C} / \mathrm{min}$. The final temperature was held for $15 \mathrm{~min}$. The injector and detector temperatures were $225^{\circ}$ and $285^{\circ} \mathrm{C}$, respectively. The data are reported as mean values ( \pm standard deviation) of at least three triplicates and the mean values are expressed as \% of a fatty acid in total fatty acid.

Lipid oxidation: Lipid oxidation of the cooked egg gels was measured using 2thiobarbituric acid reactive substances (TBARS) assay. This method measured concentration of malondialdehyde (MDA) as $\mathrm{mg} / \mathrm{kg}$ cooked gel sample. The absorbance was measured at $535 \mathrm{~nm}$ using a UV/VIS spectrophotometer (model DU530, Beckman Instruments, Fullerton, CA) and the measurement was calculated using the molar absorptivity of MDA $\left(156,000 \mathrm{M}^{-1} \mathrm{~cm}^{-1}\right)$. The data are reported as mean values $( \pm$ standard deviation).

Statistical Analysis: Experiments were run in triplicate $(n=3)$. There were at least three measurements performed in each triplicate. The mean, standard deviations, and significant differences were calculated using SAS 9.4 (SAS Institute, Cary, NC). Two-way analysis of variance (ANOVA), linear regression and Tukey's Honestly Significant Differences Test were used to analyze and report data. Microbiological data were calculated as logarithms of the number of colony forming units (cfu/g). Results for all analyses were reported as means \pm SD. A p-value of $(\mathrm{p}<0.05)$ was used to determine significance. 


\section{RESULTS AND DISCUSSION}

\section{Physiological weight loss}

Physiological loss in weight (PLW) during shelf life due to syneresis was

determined. All treatments showed significant loss $(\mathrm{p}<0.05)$ in weight over time. Eggs in vacuum packaging resulted in the greatest loss. This is also probably attributed to the increased water loss due to the squeezing of the vacuum package mentioned earlier. Eggs wrapped aerobically had significantly lower $(\mathrm{p}<0.05)$ loss when compared to eggs that were vacuum packed. This may be explained by the fact that eggs stored aerobically had an increase in $\mathrm{pH}$. Foods with higher $\mathrm{pH}$ levels tend to have lower syneresis (Nath et al., 1973). This may also be explained by the access that these eggs had to oxygen, which could result in the eggs losing moisture.

\section{pH}

Changes in $\mathrm{pH}$ showed significant interactions $(\mathrm{p}<0.05)$ due to treatment and storage time. Results for $\mathrm{pH}$ can be found in table 2. Egg sticks packaged with aerobic wrap had a significant increase $(\mathrm{p}<0.05)$ in $\mathrm{pH}$ over the 28 - day period, with the eggs in the $4^{\circ} \mathrm{C}$ group significantly $(\mathrm{p}<0.05)$ higher than those of the $10^{\circ} \mathrm{C}$ group. Egg sticks in the vacuum pack group saw significant reduction $(\mathrm{p}<0.05)$ in $\mathrm{pH}$ between day 0 and day 28; however, there were no significant changes between the two temperatures in the vacuum pack groups. A study by Karabagias et al. explained an increase in $\mathrm{pH}$ as a result of protein breakdown during spoilage, which results in the production of free amino acids 
and the formation of more alkaline NH3 and amines (Karabagias et al., 2011). These results are contradictory to those of many studies including Akyurek et al. who saw increased pH throughout storage of whole eggs (Akyurek et al., 2009). Alternatively, McMeekin et al. saw a decrease in $\mathrm{pH}$ of vacuum packed sand flat head fillets over a storage period of 6 days at $4{ }^{\circ} \mathrm{C}$ and Hur et al. found that the $\mathrm{pH}$ of chicken was significantly higher when stored in ziplock bags than in vacuum packaging for a 14 day period (McMeekin et al., 1982, Hur et al., 2013). Karabagias et al. reported that growth of lactic acid bacteria and loss of $\mathrm{CO} 2$ can result in increased $\mathrm{pH}$ in meat over storage time (Karabagias et al., 2011). A decreased or maintained $\mathrm{pH}$ is desirable in order to maintain sensory qualities of the egg, whereas an increase in $\mathrm{pH}$ value generally results in negative flavor changes. Foods with low pH are more likely to have a longer shelf life due to a reduced microbial growth at lower pH (Hur et al., 2013, Karabagias et al., 2011).

\section{Texture analysis}

Changes in texture were measured using texture profile analysis. Results for TPA can be found in table 3 . Hardness increased significantly $(\mathrm{p}<0.05)$ in all groups throughout the 28-day period. Increase in hardness over storage period is commonly seen in foods, most likely due to water loss (Oblinger et al., 1974). Springiness did not change significantly in any treatment group or throughout time. Cohesiveness was significantly $(\mathrm{p}<0.05)$ reduced in vacuum groups and increased in plastic groups. This may be due to the development of slime on eggs, which were wrapped aerobically.

Gumminess increased significantly $(\mathrm{p}<0.05)$ in all groups by day 28 . There was a significant interaction between package and day $(\mathrm{P}<0.0016)$. Eggs wrapped aerobically 
had the greatest increase in gumminess during storage. Gumminess of eggs stored at $10^{\circ} \mathrm{C}$ increased at a significantly $(\mathrm{p}<0.05)$ higher rate than those stored at $4{ }^{\circ} \mathrm{C}$.

Results for chewiness did not seem to follow any trend that allowed for assumptions to be made.

Kramer shear test was used to determine firmness of the egg gels. Results for Kramer can be found in figure 1. A significant interaction was seen between package and day $(\mathrm{P}<0.0001)$. Kramer values were significantly higher $(\mathrm{p}<0.05)$ in vacuum-packed groups than in aerobically wrapped groups. This could be because the vacuum pack pulls the air out and compresses the eggs, which results in a firmer texture. Vacuum packaging also cause increase water loss due to the squeezing of the meat (Payne et al., 1998). Kramer results increased significantly $(\mathrm{p}>0.05)$ in all groups between day 0 and day 28 . Over time, egg whites become increasingly firm and chewy, mostly due to moisture loss (Akyurek et al., 2009).

A previous study by Sedoski et al. examining the textural changes of egg sticks over a 14-day period found no significant changes in texture attributes during storage of eggs in vacuum packaging (Sedoski et al., 2011) .

\section{Color}

Color values $\left(\mathrm{L}^{*}, \mathrm{a}^{*}, \mathrm{~b}^{*}\right)$ are shown in table 4 . There was no significant change in $\mathrm{L}^{*}$ value over storage time in any treatment. Color a* decreased significantly in all treatments throughout time. There was a significant interaction between package and day $(\mathrm{p}<0.0001)$. Eggs that were wrapped aerobically and stored at $10^{\circ} \mathrm{C}$ had significantly $(\mathrm{p}<0.05)$ higher decreases in $\mathrm{a}^{*}$ values by day 28 . All a* values had a negative value, indicating greenish hues. These results are consistent with the results of Sedoski et al., 
which reported a negative $\mathrm{a}^{*}$ value in egg sticks made with whole egg (Sedoski et al., 2011). The color of the $\omega-3$ egg sticks in this study should closely resemble that of the whole egg since lutein, the carotenoid which gives the yolk its yellow color, was used to color the $\omega-3$ egg stick. There was no significant difference between vacuum treatment and temperature. Color b showed a slight decrease over time, but was not a statistically significant change. All $b^{*}$ values were found to be positive, signifying yellowish coloration. Although values of $\mathrm{L}^{*}, \mathrm{a}^{*}$, and $\mathrm{b}^{*}$ had significant changes, there were no visual losses in yellow color throughout the 28 day period; however, red colored growth did appear on aerobically wrapped eggs that were stored at $10^{\circ} \mathrm{C}$ by day 21 , which further darkened to a black color by day 28 .

Carotenoids, such as lutein, are relatively stable between a pH of 2 and 8 . However, carotenoids can fade under the presence of oxygen, low $\mathrm{pH}$, and exposure to light (Boon et al., 2010).

\section{Microbiological Analysis}

Changes in microbial populations for total plate count (TPC), anaerobic plate count (APC), and psychrotrophic plate count (PPC) in omega-3 egg sticks are shown in figure 2. For total plate count (TPC), viable growth was recorded in both aerobic wrap and vacuum treatments at $10^{\circ} \mathrm{C}$ on day 7 . Growth was much more rapid in aerobic, $10^{\circ}$ eggs; however, growth of this group leveled off around day 21 of storage and remained around $8 \log (\mathrm{CFU} / \mathrm{g})$ for the remainder of storage. Bacterial growth continued to grow steadily in eggs that were vacuumed at $10^{\circ} \mathrm{C}$ until day 28 . No viable growth was recorded in aerobic wrap at $4{ }^{\circ} \mathrm{C}$ until after day 14 and in the vacuum at $4{ }^{\circ} \mathrm{C}$ group until day 21. At day 21, eggs packaged with aerobic wrap had significantly higher growth 
than those which were vacuum packed. Eggs stored at $10^{\circ} \mathrm{C}$ in both packaging groups showed significantly higher bacterial growth than those stored at $4{ }^{\circ} \mathrm{C}$. At day 28 bacterial counts in vacuum at $4^{\circ} \mathrm{C}$ were significantly $(\mathrm{p}<0.05)$ lower than those in all other groups. Total growth was reduced throughout shelf life for vacuum packaged samples. This confirms that vacuum pack plus refrigeration $4^{\circ} \mathrm{C}$ significantly reduces total growth. In a study by Oblinger et al, peeled, hard cooked eggs stored at $5^{\circ} \mathrm{C}$ did not show viable bacterial growth until day 21 of storage when eggs were stored in sealed jars (Oblinger et al., 1974).

Anaerobic growth was recorded in order to observe differences in growth between vacuum packaging and aerobic wrapping. No viable anaerobic growth was seen until days $14-21$ where growth is recorded in vacuum $10^{\circ} \mathrm{C}$. Growth in vacuum packaged eggs was significantly higher than that of aerobic wrap groups throughout all 28 days. At day 28 , growth was significantly $(\mathrm{p}<0.05)$ higher in all groups at $10^{\circ} \mathrm{C}$ than at $4^{\circ} \mathrm{C}$. Anaerobic growth was significantly $(\mathrm{p}<0.05)$ higher in vacuum groups than aerobic wrap at day 28. There was no significant difference between temperature groups at day 28 .

Psychrotrophic plate count (PPC) was recorded to observe bacterial growth at refrigerated temperatures. No viable growth was recorded in eggs packaged at $10^{\circ} \mathrm{C}$. Initial growth was recorded between days $7-14$ in vacuum $4{ }^{\circ} \mathrm{C}$ and plastic $4{ }^{\circ} \mathrm{C}$ groups. Eggs packaged in aerobic wrap resulted in significantly $(\mathrm{p}<0.05)$ higher bacterial counts than eggs that were vacuum packed.

According to the Compendium of Methods for Microbiological Examination of Foods, total plate count should be less than 25,000 organisms/g for all egg products, including hard-cooked eggs (Salfinger et al., 2015). If this is the case, results from the current 
study would give vacuum packaged eggs stored at $4^{\circ} \mathrm{C}$ at least a 21 day storage period before they reached this limit while all other treatments would have a shelf life of at least one week shorter than this. However, further research would need to be conducted in order to verify these results. Microbiological end points for psychrotrophic or anaerobic plate counts were not found for eggs.

\section{Proximate Composition}

Results for proximate composition measurements can be found in table 5. No significant changes were seen in moisture; however, moisture had a higher reduction in eggs that were vacuum packed throughout time. According to Payne et al., vacuum packaging can cause increased syneresis due to the squeezing or compression of the meat during vacuum packing (Payne et al., 1998). There were no significant changes in fat percent or in ash. Nitrogen percent increased significantly $(\mathrm{p}<0.05)$ throughout storage in vacuum packaged eggs at both $4^{\circ} \mathrm{C}$ and $10^{\circ} \mathrm{C}$. The interaction between package type and day was significant $(\mathrm{p}<0.0001)$. These results are contrary to that of many studies, but similar results were seen by Ali et al., who found that the protein content of cooked rice stored at room temperature for 24 hours was comparatively higher than that of cooked rice stored at $4^{\circ} \mathrm{C}$. They contributed the increased protein to the increased growth of microorganisms and that an average bacterial body may contain 15\% protein (Ali., 2008). Eggs that were wrapped aerobically did not have significant changes at either temperature.

\section{Fatty acid profile}

The total fatty acid content was determined for the cooked egg gels. Results for fatty acid profile can be found in table 6 . The $\omega-6 / 3$ ratio was $0.31 \pm 0.01$, which is 
approximately a 1:3 ratio. The recommended ratio is $1: 1$ or $4: 1$ in the total diet. There was a decrease in both omega- 3 and omega- 6 fatty acids throughout time, but the decrease was only significant in EPA, DHA, and ARA. This could be due to the fact that they are longer chain fatty acids and highly unsaturated, increasing the chances of oxidation (Botsoglou et al., 2012). There was a significant decrease in EPA between days $(\mathrm{p}<0.001)$ but no interaction was found between treatment and day. The decrease started at day 14 and continued until day-28 in all groups except eggs vacuum packed at $4^{\circ} \mathrm{C}$. Eggs wrapped aerobically at $10^{\circ} \mathrm{C}$ had the highest rate of decrease in EPA. DHA showed a significant reduction throughout time $(\mathrm{P}<0.0001)$ and significant differences between treatments $(\mathrm{p}<0.03)$ and also a significant interaction between treatment and day $(\mathrm{p}<0.001)$. DHA was significantly lower in all treatments between day 0 and day 28 . Eggs wrapped aerobically seemed to show the greatest reduction and again, $10^{\circ} \mathrm{C}$ seemed to have the most accelerated reduction. These changes, however, in EPA, DHA, and ARA did not have a significant effect on the $\omega-6 / \omega-3$ ratio. These eggs have higher or lower ratio than normal egg.

\section{Lipid oxidation}

Lipid oxidation was measured using TBARS assay. Results are TBARS are reported in table 7 . There was a significant interaction $(\mathrm{p}<0.02)$ between packaging type and day throughout the 28-day period. The concentration of MDA $(\mathrm{mg} / \mathrm{kg})$ increased significantly $(\mathrm{p}<0.05)$ in all treatments during the storage period, which was to be expected. Samples in vacuum pack groups showed a significantly $(\mathrm{p}<0.05)$ slower increase in MDA throughout storage period when compared to aerobically wrapped eggs and had significantly lower levels of MDA by day 28. Numerous studies have reported 
that vacuum packaging results in decreased lipid oxidation as a result of a reduction of oxygen present. A 28-day shelf life study by Akter et al. showed that the MDA (mg/kg) of conventional eggs was approximately $1 \mathrm{mg} / \mathrm{kg}$ after 28 days of storage (Akter et al., 2014). Similarly, a study by Sedoski at al. showed an MDA concentration of $2.7 \pm 1.4$ at the end of a 14-day storage period. In the current study, all treatments resulted in significantly higher MDA concentration by day 28 than that of conventional eggs in other studies (Sedoski et al., 2011). This indicates that egg sticks containing $\omega$-3 fatty acids had more rapid lipid oxidation resulting in a range of $3.50 \pm 0.57$ in the vacuum packed $10^{\circ} \mathrm{C}$ group to $5.63 \pm 0.20$ in aerobic overwrap $10^{\circ} \mathrm{C}$ group. This is most likely due to the addition of $\omega-3$ PUFAs, which increase the probability of lipid oxidation due to the high level of unsaturation and unstable nature of these long-chain fatty acids. Storage temperature did not have a significant effect $(\mathrm{p}>0.05)$ on lipid oxidation throughout the storage period.

\section{Conclusions}

Based on this study, it can be concluded that both vacuum packing and refrigeration at $4{ }^{\circ} \mathrm{C}$ have a significant impact on decreasing the rate at which $\omega$ - 3 egg sticks degrade over time. Eggs from this treatment group had significantly lower levels of MDA (mg/kg), lower oxidation of $\omega-3$ fatty acids, fewer textural changes, and significantly $(\mathrm{p}<0.05)$ lower rates of microbial growth for total plate count; however, these eggs had higher values for hardness, high anaerobic plate count and the largest water losses over the storage period which was most likely due to the vacuum packaging. Analyzing the results, it could be inferred that when vacuum packed and stored at $4^{\circ} \mathrm{C}, \omega$ 3 egg sticks may maintain storage stability for at least 21 days. Sensory evaluation 
should be conducted in the future in order to determine the point at which the $\omega-3$ egg sticks have lost sensory and organoleptic qualities and are no longer desirable to the consumer. 


\section{REFERENCES}

Age-Related Eye Disease Study 2 Research Group. (2013). Lutein + zeaxanthin and omega-3 fatty acids for age-related macular degeneration: the Age-Related Eye Disease Study 2 (AREDS2) randomized clinical trial. JAMA, 309(19), 2005-2015. http://doi.org/10.1001/jama.2013.4997

Akter, Y., Kasim, A., Omar, H., \& Sazili, A. Q. (2014). Effect of storage time and temperature on the quality characteristics of chicken eggs. Journal of Food Agriculture and Environment, 1212(3\&4), 87-92.

Akyurek, H., \& Agma, A. (2009). Effect of Storage Time, Temperature and Hen Age on Egg Quality in Free-Range Layer Hens. Journal of Animal and Veterinary Advances, 8(10), 1953-1958.

Ali, M. A., Hasan, S. M. K., \& Islam, M. N. (2008). Study on the period of acceptability of cooked rice. Journal of Bangladesh Agril. University, 6(2), 401-408.

Artham, S. M., Lavie, C. J., Milani, R. V., Anand, R. G., O’Keefe, J. H., \& Ventura, H. O. (2008). Fish Oil in Primary and Secondary Cardiovascular Prevention. The Ochsner Journal, 8(2), 49-60.

Baucells, M. D., Crespo, N., Barroeta, A. C., López-Ferrer, S., \& Grashorn, M. A. (2000). Incorporation of different polyunsaturated fatty acids into eggs. Poultry Science, 79(1), 51-59. http://doi.org/10.1093/ps/79.1.51

Blasbalg, T. L., Hibbeln, J. R., Ramsden, C. E., Majchrzak, S. F., \& Rawlings, R. R. (2011). Changes in consumption of omega-3 and omega-6 fatty acids in the United States during the 20th century. The American Journal of Clinical Nutrition, 93(5), 950-962. http://doi.org/10.3945/ajcn.110.006643 
Boon, C. S., McClements, D. J., Weiss, J., \& Decker, E. A. (2010). Factors influencing the chemical stability of carotenoids in foods. Critical Reviews in Food Science and Nutrition, 50(6), 515-532. http://doi.org/10.1080/10408390802565889

Botsoglou, E., Govaris, A., Pexara, A., \& Fletouris, D. (2012). Effect of processing and storage on the fatty acid composition of n-3 or n-6 fatty acid-enriched eggs. International Journal of Food Science \& Technology, 47(11), 2388-2396. http://doi.org/10.1111/j.1365-2621.2012.03114.x

Chung, H.-Y., Rasmussen, H. M., \& Johnson, E. J. (2004). Lutein Bioavailability Is Higher from Lutein-Enriched Eggs than from Supplements and Spinach in Men. The Journal of Nutrition, 134(8), 1887-1893.

Coorey, R., Novinda, A., Williams, H., \& Jayasena, V. (2015). Omega-3 Fatty Acid Profile of Eggs from Laying Hens Fed Diets Supplemented with Chia, Fish Oil, and Flaxseed. Journal of Food Science, 80(1), S180-S187. http://doi.org/10.1111/1750-3841.12735

Dawczynski, J., Jentsch, S., Schweitzer, D., Hammer, M., Lang, G. E., \& Strobel, J. (2013). Long term effects of lutein, zeaxanthin and omega-3-LCPUFAs supplementation on optical density of macular pigment in AMD patients: the LUTEGA study. Graefe's Archive for Clinical and Experimental Ophthalmology, 251(12), 2711-2723. http://doi.org/10.1007/s00417-013-2376-6

DeFilippis, A. P., Blaha, M. J., \& Jacobson, T. A. (2010). Omega-3 Fatty Acids for Cardiovascular Disease Prevention. Current Treatment Options in Cardiovascular Medicine, 12(4), 365-380. http://doi.org/10.1007/s11936010-0079-4 
Dias CB, Garg R, Wood LG, \& Garg ML. (2014). Saturated fat consumption may not be the main cause of increased blood lipid levels. Medical Hypotheses, 82(2), 187-95.

Dietary Guidelines for Americans. 8th Edition. (2015, December). U.S. Department of Health and Human Services and U.S. Department of Agriculture. Retrieved from http://health.gov/dietaryguideilnes/2015/guidelines/

Ercolini, D., Russo, F., Nasi, A., Ferranti, P., \& Villani, F. (2009). Mesophilic and Psychrotrophic Bacteria from Meat and Their Spoilage Potential In Vitro and in Beef. Applied and Environmental Microbiology, 75(7), 1990-2001. http://doi.org/10.1128/AEM.02762-08

Goyens, P. L., Spilker, M. E., Zock, P. L., Katan, M. B., \& Mensink, R. P. (2006). Conversion of $\alpha$-linolenic acid in humans is influenced by the absolute amounts of $\alpha$-linolenic acid and linoleic acid in the diet and not by their ratio. The American Journal of Clinical Nutrition, 84(1), 44-53.

Gray, J. I., Gomaa, E. A., \& Buckley, D. J. (1996). Oxidative quality and shelf life of meats. Meat Science, 43, Supplement 1, 111-123. http://doi.org/10.1016/0309-1740(96)00059-9

Hayes, J. E., Stepanyan, V., Allen, P., O'Grady, M. N., \& Kerry, J. P. (2011). Evaluation of the effects of selected plant-derived nutraceuticals on the quality and shelflife stability of raw and cooked pork sausages. LWT - Food Science and Technology, 44(1), 164-172. http://doi.org/10.1016/j.lwt.2010.05.020

He, K. (2009). Fish, Long-Chain Omega-3 Polyunsaturated Fatty Acids and Prevention of Cardiovascular Disease-Eat Fish or Take Fish Oil 
Supplement? Progress in Cardiovascular Diseases, 52(2), 95-114. http://doi.org/10.1016/j.pcad.2009.06.003

Hur, S. J., Jin, S. K., Park, J. H., Jung, S. W., \& Lyu, H. J. (2013). Effect of Modified Atmosphere Packaging and Vacuum Packaging on Quality Characteristics of Low Grade Beef during Cold Storage. Asian-Australasian Journal of Animal Sciences, 26(12), 1781-1789. http://doi.org/10.5713/ajas.2013.13225

Jan, S., Brunet, N., Techer, C., Le Maréchal, C., Koné, A. Z., Grosset, N., ... Baron, F. (2011). Biodiversity of psychrotrophic bacteria of the Bacillus cereus group collected on farm and in egg product industry. Food Microbiology, 28(2), 261265. http://doi.org/10.1016/j.fm.2010.05.029

Karabagias, I., Badeka, A., \& Kontominas, M. G. (2011). Shelf life extension of lamb meat using thyme or oregano essential oils and modified atmosphere packaging. Meat Science, 88(1), 109-116. http://doi.org/10.1016/j.meatsci.2010.12.010

Kassis, N., Drake, S. R., Beamer, S. K., Matak, K. E., \& Jaczynski, J. (2010). Development of nutraceutical egg products with omega-3-rich oils. LWT Food Science and Technology, 43(5), 777-783. http://doi.org/10.1016/j.lwt.2009.12.014

Kassis, N. M., Beamer, S. K., Matak, K. E., Tou, J. C., \& Jaczynski, J. (2010). Nutritional composition of novel nutraceutical egg products developed with omega-3rich oils. LWT - Food Science and Technology, 43(8), 1204-1212. http://doi.org/10.1016/j.lwt.2010.04.006 
Kilcast, D., \& Subramaniam, P. (2011). Food and Beverage Stability and Shelf Life. Oxford; Philadelphia: Woodhead Pub., 2011.

Kralik, Z., Kralik, G., Grcevic, M., \& Galovic, D. (2014). Effect of Storage Period on the Quality of Table Eggs. Acta Agraria Kaposvariensis, 18(1), 200-206. http://doi.org/10.13140/2.1/3231/3285

Kris-Etherton, P. M., Grieger, J. A., \& Etherton, T. D. (2009). Dietary reference intakes for DHA and EPA. Prostaglandins, Leukotrienes and Essential Fatty Acids, 81(2-3), 99-104. http://doi.org/10.1016/j.plefa.2009.05.011

Kris-Etherton, P. M., Harris, W. S., Appel, L. J., \& Committee, for the N. (2002). Fish Consumption, Fish Oil, Omega-3 Fatty Acids, and Cardiovascular Disease. Circulation, 106(21), 2747-2757. http://doi.org/10.1161/01.CIR.0000038493.65177.94

Lavie, C. J., Milani, R. V., Mehra, M. R., \& Ventura, H. O. (2009). Omega-3 Polyunsaturated Fatty Acids and Cardiovascular Diseases. Journal of the American College of Cardiology, 54(7), 585-594. http://doi.org/10.1016/j.jacc.2009.02.084

Leeson, S., \& Caston, L. (2004). Enrichment of Eggs with Lutein. Poultry Science, 83(10), 1709-1712. http://doi.org/10.1093/ps/83.10.1709

Lorenzo JM, \& Gómez M. (2012). Shelf life of fresh foal meat under MAP, overwrap and vacuum packaging conditions. Meat Science, 92(4), 610-8.

Love, J. D., \& Pearson, A. M. (1971). Lipid oxidation in meat and meat products-A review. J Am Oil Chem Soc Journal of the American Oil Chemists' Society, 48(10), 547-549. 
Magrone, T., de Heredia, F., Jirillo, E., Morabito, G., Marcos, A., \& Serafini, M. (2013). Functional food and nutraceuticals as therapeutic tools for the treatment of diet related diseases. Canadian Journal of Psyology and Pharmacology. NRC Research Press, 91, 387-396.

McMeekin, T., Hulse, L., \& Bremner, H. (1982). Spoilage association of vacuum packed sand flathead (Platycephalus bassensis) fillets. Food Australia, 34(6), 278-282.

Mozaffarian, D., \& Wu, J. H. Y. (2011). Omega-3 Fatty Acids and Cardiovascular Disease: Effects on Risk Factors, Molecular Pathways, and Clinical Events. Journal of the American College of Cardiology, 58(20), 2047-2067. http://doi.org/10.1016/j.jacc.2011.06.063

Nath, K. R., Darfler, J. M., \& Baker, R. C. (1973). Prevention of Exudation of Hard Cooked Packaged Eggs. Poultry Science, 52(5), 1827-1830. http://doi.org/10.3382/ps.0521827

Oblinger, J. L., \& Angalet, S. A. (1974). Storage Stability of Hard-Cooked Eggs. Poultry Science, 53(4), 1415-1420. http://doi.org/10.3382/ps.0531415

Papanikolaou, Y., Brooks, J., Reider, C., \& Fulgoni, V. L. (2014). U.S. adults are not meeting recommended levels for fish and omega-3 fatty acid intake: results of an analysis using observational data from NHANES 2003-2008. Nutrition Journal, 13, 31. http://doi.org/10.1186/1475-2891-13-31

Payne, S. R., Durham, C. J., Scott, S. M., \& Devine, C. E. (1998). The effects of nonvacuum packaging systems on drip loss from chilled beef. Meat Science, $49(3), 277-287$. 
Richer, S., Stiles, W., Statkute, L., Pulido, J., Frankowski, J., Rudy, D., ... Nyland, J. (2004). Double-masked, placebo-controlled, randomized trial of lutein and antioxidant supplementation in the intervention of atrophic age-related macular degeneration: the Veterans LAST study (Lutein Antioxidant Supplementation Trial). Optometry (St. Louis, Mo.), 75(4), 216-230.

Ripoll, G., Joy, M., \& Muñoz, F. (2011). Use of dietary vitamin E and selenium (Se) to increase the shelf life of modified atmosphere packaged light lamb meat. Meat Science, 87(1), 88-93. http://doi.org/10.1016/j.meatsci.2010.09.008

Rosenthal, J. M., Kim, J., de Monastario, F., Thompson, D. J. S., Bone, R. A., Landrum, J. T., ... Chew, E. Y. (2006). Dose-Ranging Study of Lutein Supplementation in Persons Aged 60 Years or Older. Investigative Opthalmology \& Visual Science, 47(12), 5227. http://doi.org/10.1167/iovs.05-1513

Salfinger, Y., \& Tortorell, L. (2015). Compendium of methods for the microbiological examination of foods (5th ed.).

Sedoski, H. D. (2011). Sensory Evaluation and Quality Indicators of Nutritionally Enhanced Egg Product with Omega-3 Rich Oils (M.S.). West Virginia University, United States -- West Virginia. Retrieved from http://search.proquest.com.www.libproxy.wvu.edu/docview/894257926/a bstract/34C6835A2D4B4687PQ/1

Shahidi, F. (2004). Functional Foods: Their Role in Health Promotion and Disease Prevention. JFDS Journal of Food Science, 69(5), R146-R149. 
Shahidi, F., \& Zhong, Y. (2010). Novel antioxidants in food quality preservation and health promotion. European Journal of Lipid Science and Technology, 112(9), 930-940. http://doi.org/10.1002/ejlt.201000044

Simopoulos, A. P. (2002). The importance of the ratio of omega-6/omega-3 essential fatty acids. Biomedicine \& Pharmacotherapy, 56(8), 365-379. http://doi.org/10.1016/S0753-3322(02)00253-6

S. Jan, \& F. Baron. (2015). 32. Psychrotrophic heat-resistant bacteria in the sector of pasteurized liquid egg processing: a focus on the Bacillus cereus group. In Handbook of eggs in human function (Vol. 9, pp. 577-614). Wageningen Academic Publishers. Retrieved from http://www.wageningenacademic.com/doi/abs/10.3920/978-90-8686804-9_32

The American Heart Association. (2016). Retrieved from http://www.heart.org/HEARTORG/HealthyLiving/HealthyLiving_UCM_001078_SubHomePage.jsp

The U.S. Department of Agriculture Food Safety and Inspection Service. (2016). Retrieved from http://www.fsis.usda.gov/wps/portal/fsis/topics/foodsafety-education/get-answers/food-safety-fact-sheets/egg-productspreparation/shell-eggs-from-farm-to-table/CT_Index

Tokuşoğlu, Ö. (2013). The physicochemical, microbiological, organoleptic properties and antioxidant activities of functional cream cheeses fortified with lutein. International Journal of Dairy Technology, 66(4), 527-534. http://doi.org/10.1111/1471-0307.12070 
Wall, R., Ross, R. P., Fitzgerald, G. F., \& Stanton, C. (2010). Fatty acids from fish: the anti-inflammatory potential of long-chain omega-3 fatty acids. Nutrition Reviews, 68(5), 280-289. http://doi.org/10.1111/j.1753-4887.2010.00287.x

Wang, M.-X., Jiao, J.-H., Li, Z.-Y., Liu, R.-R., Shi, Q., \& Ma, L. (2013). Lutein supplementation reduces plasma lipid peroxidation and C-reactive protein in healthy nonsmokers. Atherosclerosis, 227(2), 380-385. http://doi.org/10.1016/j.atherosclerosis.2013.01.021

Weech, M., Vafeiadou, K., Hasaj, M., Todd, S., Yaqoob, P., Jackson, K. G., \& Lovegrove, J. A. (2014). Development of a Food-Exchange Model to Replace Saturated Fat with MUFAs and n-6 PUFAs in Adults at Moderate Cardiovascular Risk. The Journal of Nutrition, 144(6), 846-855. http://doi.org/10.3945/jn.114.190645 
Table 1

Syneresis of $\omega-3$ egg sticks packaged under vacuum or aerobic wrap at $4{ }^{\circ} \mathrm{C}$ and $10^{\circ} \mathrm{C}$ over a 28 -day period.

\begin{tabular}{|c|c|c|c|c|c|}
\hline \multirow[t]{2}{*}{ Attribute } & \multirow[t]{2}{*}{ Packaging } & \multicolumn{4}{|l|}{ Days of Storage } \\
\hline & & 7 & 14 & 21 & 28 \\
\hline \multirow[t]{4}{*}{$\% \mathrm{PLW}$} & Vac. $4^{\circ}$ & $7.26 \pm 0.58^{\mathrm{Hb}}$ & $12.37 \pm 0.34^{\mathrm{Ba}}$ & $12.43 \pm 0.38^{\mathrm{Ba}}$ & $12.26 \pm 0.57^{\mathrm{Bb}}$ \\
\hline & Vac. $10^{\circ}$ & $10.12 \pm 0.76^{\mathrm{Da}}$ & $11.2 \pm 0.87^{\mathrm{Cb}}$ & $12.08 \pm 0.15^{\mathrm{Ba}}$ & $13.63 \pm 0.33^{\mathrm{Aa}}$ \\
\hline & Non-vac. $4^{\circ}$ & $1.62 \pm 0.66^{\mathrm{Kd}}$ & $1.82 \pm 0.27^{\mathrm{Kd}}$ & $2.65 \pm 0.27^{\mathrm{Hc}}$ & $3.63 \pm 0.22^{\mathrm{Jd}}$ \\
\hline & Non-vac. $10^{\circ}$ & $5.16 \pm 0.16^{\mathrm{Ic}}$ & $7.88 \pm 0.21^{\mathrm{Gc}}$ & $8.33 \pm 0.53^{\mathrm{Fb}}$ & $8.92 \pm 0.51^{\mathrm{Ec}}$ \\
\hline
\end{tabular}

Different capital letters show significant differences between days $(\mathrm{p}<0.05)$ determined by Tukey's HSD. Different lowercase letters represent significant differences between treatment groups $(\mathrm{p}<0.05)$ determined by Tukey's HSD.

${ }^{a}$ Values are mean score \pm SD $(n=3)$. 
Table 2

$\mathrm{pH}^{\mathrm{a}}$ of $\omega$-3 egg sticks packaged under vacuum or aerobic wrap at $4^{\circ} \mathrm{C}$ and $10^{\circ} \mathrm{C}$ over a 28 -day period.

\begin{tabular}{|c|c|c|c|c|c|c|}
\hline Attribute & Packaging & Days of Storage & & & & \\
\hline $\mathrm{pH}$ & & 0 & 7 & 14 & 21 & 28 \\
\hline & $\mathrm{VF}$ & $8.47 \pm 0.01^{\mathrm{Dc}}$ & $8.27 \pm 0.04^{\mathrm{Ed}}$ & $8.25 \pm 0.01^{\mathrm{Ed}}$ & $7.67 \pm 0.01^{\mathrm{FGe}}$ & $7.65 \pm 0.00^{\mathrm{Ge}}$ \\
\hline & V10 & $8.47 \pm 0.05^{\mathrm{Dc}}$ & $7.71 \pm 0.05^{\mathrm{Fe}}$ & $7.15 \pm 0.03^{\text {If }}$ & $7.61 \pm 0.01^{\mathrm{GHe}}$ & $7.67 \pm 0.00^{\mathrm{FGe}}$ \\
\hline & $\mathrm{PF}$ & $8.48 \pm 0.02^{\mathrm{Dc}}$ & $9.09 \pm 0.01^{\mathrm{ABa}}$ & $9.15 \pm 0.01^{\mathrm{Aa}}$ & $7.57 \pm 0.01^{\mathrm{He}}$ & $6.98 \pm 0.01^{\mathrm{Jg}}$ \\
\hline & P10 & $8.49 \pm 0.01^{\mathrm{Dc}}$ & $9.03 \pm 0.02^{\mathrm{Ba}}$ & $8.88 \pm 0.01^{\mathrm{Cb}}$ & $7.68 \pm 0.01^{\mathrm{Fe}}$ & $7.12 \pm 0.01^{\mathrm{Af}}$ \\
\hline
\end{tabular}

Within each set of data, different capital letters show significant differences between days $(\mathrm{p}<0.05)$ determined by Tukey's HSD. Different lowercase letters represent significant differences between treatment groups $(p<0.05)$ determined by Tukey's HSD.

a Values are mean score \pm SD $(n=8)$. 
Table 3

Texture profile analysis (TPA) $)^{\mathrm{a}}$ of $\omega$-3 egg sticks under vacuum or aerobic wrap at $4^{\circ} \mathrm{C}$ and $10^{\circ} \mathrm{C}$ over a 28 -day period.

\begin{tabular}{|c|c|c|c|c|c|c|}
\hline \multirow[t]{2}{*}{ Attribute } & \multirow[t]{2}{*}{ Packaging } & \multicolumn{5}{|l|}{ Days of storage } \\
\hline & & 0 & 7 & 14 & 21 & 28 \\
\hline \multirow[t]{4}{*}{ Hardness (g) } & Vac. $4^{\circ}$ & $547.26 \pm 56.84^{\mathrm{ABCa}}$ & $335.48 \pm 54.82^{\mathrm{CDEFGb}}$ & $377.68 \pm 13.06^{\mathrm{BCDEFGd}}$ & $484.08 \pm 27.32^{\mathrm{ABCDEb}}$ & $325.35 \pm 65.04^{\mathrm{DEFGc}}$ \\
\hline & Vac. $10^{\circ}$ & $515.63 \pm 37.65^{\mathrm{ABCDb}}$ & $266.81 \pm 42.80^{\mathrm{Gc}}$ & $455.15 \pm 54.10^{\text {BCDEFGb }}$ & $337.44 \pm 86.29^{\mathrm{CDEFGd}}$ & $306.39 \pm 49.58^{\mathrm{EFGc}}$ \\
\hline & Plastic $4^{\circ}$ & $504.16 \pm 45.75^{\mathrm{ABCDEb}}$ & $277.78 \pm 38.09^{\mathrm{FGc}}$ & $385.86 \pm 90.37^{\text {BCDEFGc }}$ & $402.81 \pm 18.63^{\text {BCDEFGc }}$ & $402.04 \pm 79.85^{\text {BCDEFGb }}$ \\
\hline & Plastic $10^{\circ}$ & $531.77 \pm 50.89^{\mathrm{ABCDa}}$ & $461.98 \pm 121.13^{\text {BCDEFGa }}$ & $683.10 \pm 181.32^{\mathrm{Aa}}$ & $592.72 \pm 15.57^{\mathrm{ABa}}$ & $484.30 \pm 21.05^{\mathrm{ABCDEFG}}$ \\
\hline \multirow[t]{4}{*}{ Gumminess (g) } & Vac. $4^{\circ}$ & $169.04 \pm 33.98^{\text {BCDEFcd }}$ & $138.44 \pm 30.91^{\mathrm{EFde}}$ & $164.37 \pm 61.20^{\mathrm{CDEFb}}$ & $158.63 \pm 29.93^{\mathrm{CDEFd}}$ & $172.05 \pm 30.97^{\text {abcBCDEF }}$ \\
\hline & Vac. $10^{\circ}$ & $170.12 \pm 2.06^{\mathrm{BCDEFcd}}$ & $169.64 \pm 24.33^{\mathrm{BCDEFd}}$ & $151.12 \pm 3.51^{\mathrm{DEFd}}$ & $182.35 \pm 10.11^{\mathrm{BCDEFc}}$ & $185.39 \pm 17.77^{\mathrm{abBCDEF}}$ \\
\hline & Plastic $4^{\circ}$ & $173.22 \pm 3.91^{\text {BCDEFcd }}$ & $161.17 \pm 2.23^{\mathrm{CDEFd}}$ & $110.83 \pm 21.54^{\mathrm{Fe}}$ & $255.01 \pm 16.30^{\mathrm{fEFb}}$ & $248.10 \pm 18.62^{\text {abcfABCD }}$ \\
\hline & Plastic $10^{\circ}$ & $168.41 \pm 3.40^{\mathrm{BCDEFcd}}$ & $215.87 \pm 52.59^{\mathrm{ACDEbc}}$ & $264.91 \pm 47.52^{\mathrm{ABa}}$ & $293.55 \pm 29.68^{\mathrm{Aa}}$ & $293.56 \pm 63.35^{\mathrm{fAC}}$ \\
\hline \multirow[t]{4}{*}{ Springiness } & Vac. $4^{\circ}$ & $0.74 \pm 0.06^{\mathrm{Aa}}$ & $1.85 \pm 0.13^{\mathrm{Ab}}$ & $1.11 \pm 0.29^{\mathrm{Aa}}$ & $2.15 \pm 0.19^{\mathrm{Ab}}$ & $1.81 \pm 0.51^{\mathrm{bA}}$ \\
\hline & Vac. $10^{\circ}$ & $0.75 \pm 0.02^{\mathrm{Aa}}$ & $1.16 \pm 0.13^{\mathrm{Ba}}$ & $0.89 \pm 0.01^{\mathrm{Aa}}$ & $1.15 \pm 0.26^{\mathrm{Ba}}$ & $2.10 \pm 0.17^{\mathrm{bA}}$ \\
\hline & Plastic $4^{\circ}$ & $0.72 \pm 0.02^{\mathrm{Aa}}$ & $0.86 \pm 0.09^{\mathrm{Ba}}$ & $0.80 \pm 0.02^{\mathrm{Aa}}$ & $2.25 \pm 0.11^{\mathrm{Ab}}$ & $2.10 \pm 0.16^{\mathrm{bA}}$ \\
\hline & Plastic $10^{\circ}$ & $0.73 \pm 0.01^{\mathrm{Aa}}$ & $2.11 \pm 0.15^{\mathrm{Ab}}$ & $0.91 \pm 0.22^{\mathrm{Aa}}$ & $2.14 \pm 0.05^{\mathrm{Ab}}$ & $0.89 \pm 0.05^{\mathrm{aB}}$ \\
\hline \multirow[t]{4}{*}{ Cohesiveness } & Vac. $4^{\circ}$ & $0.39 \pm 0.06^{\mathrm{ABCc}}$ & $0.55 \pm 0.20^{\mathrm{Aa}}$ & $0.44 \pm 0.08^{\mathrm{ABCb}}$ & $0.28 \pm 0.01^{\mathrm{BCbc}}$ & $0.26 \pm 0.06^{\mathrm{Cbc}}$ \\
\hline & Vac. $10^{\circ}$ & $0.39 \pm 0.02^{\mathrm{ABCc}}$ & $0.30 \pm 0.10^{\mathrm{ABCbc}}$ & $0.52 \pm 0.04^{\mathrm{ABCa}}$ & $0.52 \pm 0.11^{\mathrm{ABa}}$ & $0.28 \pm 0.03^{\mathrm{BCbc}}$ \\
\hline & Plastic $4^{\circ}$ & $0.39 \pm 0.04^{\mathrm{ABCc}}$ & $0.40 \pm 0.16^{\mathrm{ABCb}}$ & $0.50 \pm 0.10^{\mathrm{ABCa}}$ & $0.50 \pm 0.02^{\mathrm{ABCa}}$ & $0.32 \pm 0.02^{\mathrm{ABCbc}}$ \\
\hline & Plastic $10^{\circ}$ & $0.38 \pm 0.04^{\mathrm{ABCc}}$ & $0.41 \pm 0.13^{\mathrm{ABCb}}$ & $0.53 \pm 0.02^{\mathrm{ABa}}$ & $0.47 \pm 0.09^{\mathrm{ABCab}}$ & $0.47 \pm 0.01^{\mathrm{ABCb}}$ \\
\hline \multirow[t]{4}{*}{ Chewiness } & $\operatorname{Vac} .4^{\circ}$ & $160.04 \pm 2.01^{\text {FGHde }}$ & $279.75 \pm 39.05^{\mathrm{BCDEd}}$ & $170.40 \pm 49.64^{\mathrm{EFGHde}}$ & $131.01 \pm 24.84^{\mathrm{GHg}}$ & $92.24 \pm 19.24^{\mathrm{Hh}}$ \\
\hline & Vac. $10^{\circ}$ & $162.05 \pm 2.91^{\text {FGHde }}$ & $167.79 \pm 36.89^{\mathrm{EFGHde}}$ & $155.82 \pm 61.72^{\mathrm{FGHf}}$ & $173.50 \pm 4.84^{\mathrm{EFGHde}}$ & $379.22 \pm 13.17^{\mathrm{BCb}}$ \\
\hline & Plastic $4^{\circ}$ & $159.34 \pm 1.96^{\text {FGHde }}$ & $109.35 \pm 15.01^{\mathrm{GHgh}}$ & $218.75 \pm 70.32^{\mathrm{BDd}}$ & $389.15 \pm 34.53^{\mathrm{Bb}}$ & $364.75 \pm 36.81^{\mathrm{ABCb}}$ \\
\hline & Plastic $10^{\circ}$ & $160.13 \pm 23.60^{\text {FGHde }}$ & $264.58 \pm 22.04^{\mathrm{CDEFc}}$ & $155.98 \pm 46.23^{\mathrm{FGHf}}$ & $772.74 \pm 74.24^{\mathrm{Aa}}$ & $291.17 \pm 22.75^{\mathrm{BCDc}}$ \\
\hline
\end{tabular}

Within each set of data, different lowercase letters within the same column indicate significant differences between treatments ( $p<0.05)$ determined by Tukey's HSD. Different capital letters within the same row indicate significant differences between days $(p<0.05)$ determined by Tukey's HSD.

${ }^{a}$ Values are mean score $\pm \operatorname{SD}(\mathrm{n}=9)$. 


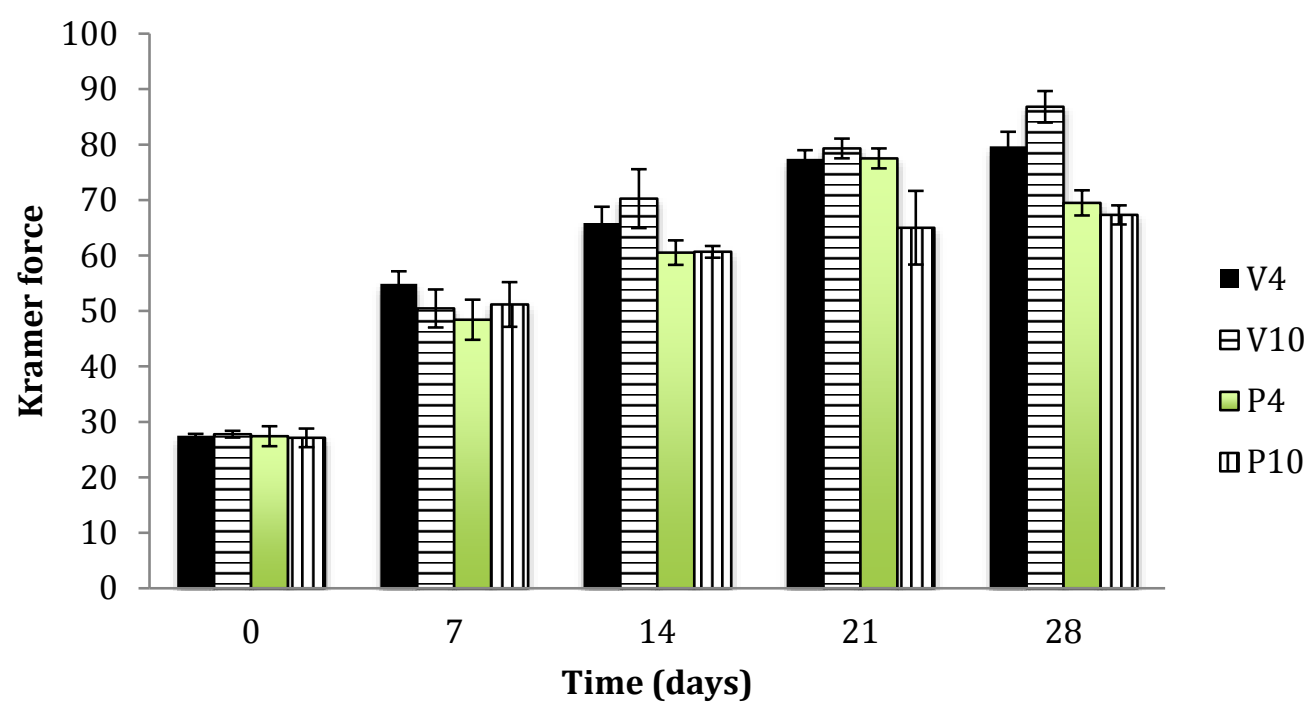

Figure 1.

Kramer shear test results for cooked egg sticks under vacuum or aerobic wrap at $4^{\circ} \mathrm{C}$ and $10^{\circ} \mathrm{C}$ over a 28 -day period. Values are mean scores $\pm S D(n=6)$. 


\section{Table 4}

Color analysis $\left(\mathrm{L}^{*}, \mathrm{a}^{*}, \mathrm{~b}^{*}\right)$ a of $\omega$-3 egg sticks under vacuum or aerobic wrap at $4^{\circ} \mathrm{C}$ and $10^{\circ} \mathrm{C}$ over a 28 -day period.

\begin{tabular}{|c|c|c|c|c|c|c|}
\hline \multirow[t]{2}{*}{ Attribute } & \multirow[t]{2}{*}{ Packaging } & \multicolumn{5}{|l|}{ Days of Storage } \\
\hline & & 0 & 7 & 14 & 21 & 28 \\
\hline \multirow[t]{4}{*}{$\mathrm{L}^{*}$} & Vac. $4^{\circ}$ & $89.99 \pm 1.22^{\text {DEFGHd }}$ & $92.17 \pm 0.27^{\mathrm{BCb}}$ & $92.19 \pm 0.84^{\mathrm{BCb}}$ & $97.34 \pm 0.37$ Аа & $91.47 \pm 0.09 \mathrm{BCDc}$ \\
\hline & Vac. $10^{\circ}$ & $88.52 \pm 0.73^{\mathrm{GHd}}$ & $91.64 \pm 0.84 \mathrm{BCDc}$ & $92.24 \pm 0.39$ ВСь & $96.53 \pm 0.94 \mathrm{Aa}$ & $91.24 \pm 0.72^{\text {ВCDEC }}$ \\
\hline & Plastic $4^{\circ}$ & $89.54 \pm 0.39 \mathrm{EFGHd}$ & $89.46 \pm 0.34 \mathrm{EFGHd}$ & $90.68 \pm 0.58$ СDEс & $96.68 \pm 0.55^{\mathrm{Aa}}$ & $90.23 \pm 0.21^{\mathrm{DEFGC}}$ \\
\hline & Plastic $10^{\circ}$ & $88.71 \pm 0.40^{\mathrm{FGHd}}$ & $90.46 \pm 0.3^{\mathrm{CDEFC}}$ & $92.56 \pm 0.57 \mathrm{Bb}$ & $95.99 \pm 1.00 \mathrm{Aa}$ & $88.18 \pm 0.86^{\mathrm{Hd}}$ \\
\hline \multirow[t]{4}{*}{$a^{*}$} & Vac. $4^{\circ}$ & $-2.56 \pm 0.23^{\mathrm{De}}$ & $-3.97 \pm 0.05^{\mathrm{Ef}}$ & $-4.05 \pm 0.20^{\mathrm{Ef}}$ & $-0.85 \pm 0.06^{\mathrm{Bc}}$ & $-3.65 \pm 0.06^{\mathrm{Ef}}$ \\
\hline & Vac. $10^{\circ}$ & $-2.23 \pm 0.16^{\mathrm{CDe}}$ & $-4.15 \pm 0.23^{\mathrm{Ef}}$ & $-3.67 \pm 0.05^{\mathrm{Ef}}$ & $-1.59 \pm 0.06^{\mathrm{BCd}}$ & $-3.51 \pm 0.49 \mathrm{Ef}$ \\
\hline & Plastic $4^{\circ}$ & $-2.25 \pm 0.06 \mathrm{De}$ & $-3.67 \pm 0.12^{\mathrm{Ef}}$ & $-3.53 \pm 0.11^{\mathrm{Ef}}$ & $-1.14 \pm 0.24 \mathrm{Bc}$ & $-3.86 \pm 0.13^{\mathrm{Ef}}$ \\
\hline & Plastic $10^{\circ}$ & $-2.25 \pm 0.07 \mathrm{CDe}$ & $-3.66 \pm 0.08^{\mathrm{Ef}}$ & $-4.20 \pm 0.25^{\mathrm{Ef}}$ & $0.34 \pm 0.17^{\mathrm{Ab}}$ & $0.61 \pm 0.05^{\text {Аа }}$ \\
\hline \multirow[t]{4}{*}{$b^{*}$} & Vac. $4^{\circ}$ & $32.29 \pm 0.18^{\mathrm{ABCa}}$ & $27.34 \pm 1.22^{\mathrm{ABCd}}$ & $24.52 \pm 0.76^{\mathrm{Ce}}$ & $26.63 \pm 0.24 \mathrm{Dd}$ & $30.10 \pm 0.60^{\mathrm{ABCb}}$ \\
\hline & Vac. $10^{\circ}$ & $33.30 \pm 1.20^{\mathrm{Aa}}$ & $26.98 \pm 0.27 \mathrm{ABCd}$ & $28.61 \pm 0.25^{\mathrm{ABCc}}$ & $28.63 \pm 0.43^{\mathrm{ABCC}}$ & $28.85 \pm 2.00^{A B C C}$ \\
\hline & Plastic 4 & $31.35 \pm 1.35^{\mathrm{ABa}}$ & $30.69 \pm 0.32^{\mathrm{ABCb}}$ & $28.87 \pm 0.66^{\mathrm{ABCc}}$ & $29.12 \pm 0.68^{\mathrm{Dc}}$ & $31.82 \pm 0.76^{\mathrm{ABa}}$ \\
\hline & Plastic $10^{\circ}$ & $32.74 \pm 0.72^{\mathrm{ABa}}$ & $28.15 \pm 1.24 \mathrm{ABCC}$ & $26.23 \pm 0.17 \mathrm{BCd}$ & $26.19 \pm 0.31^{\mathrm{Dd}}$ & $30.30 \pm 0.62^{\mathrm{ABCb}}$ \\
\hline
\end{tabular}

Different lowercase letters within the same column indicate significant differences between treatments $(\mathrm{p}<0.05)$ determined by Tukey's HSD. Different capital letters within the same row indicate significant differences between days $(\mathrm{p}<0.05)$ determined by Tukey's HSD.

a Values are mean score \pm SD $(n=5)$. 
A.
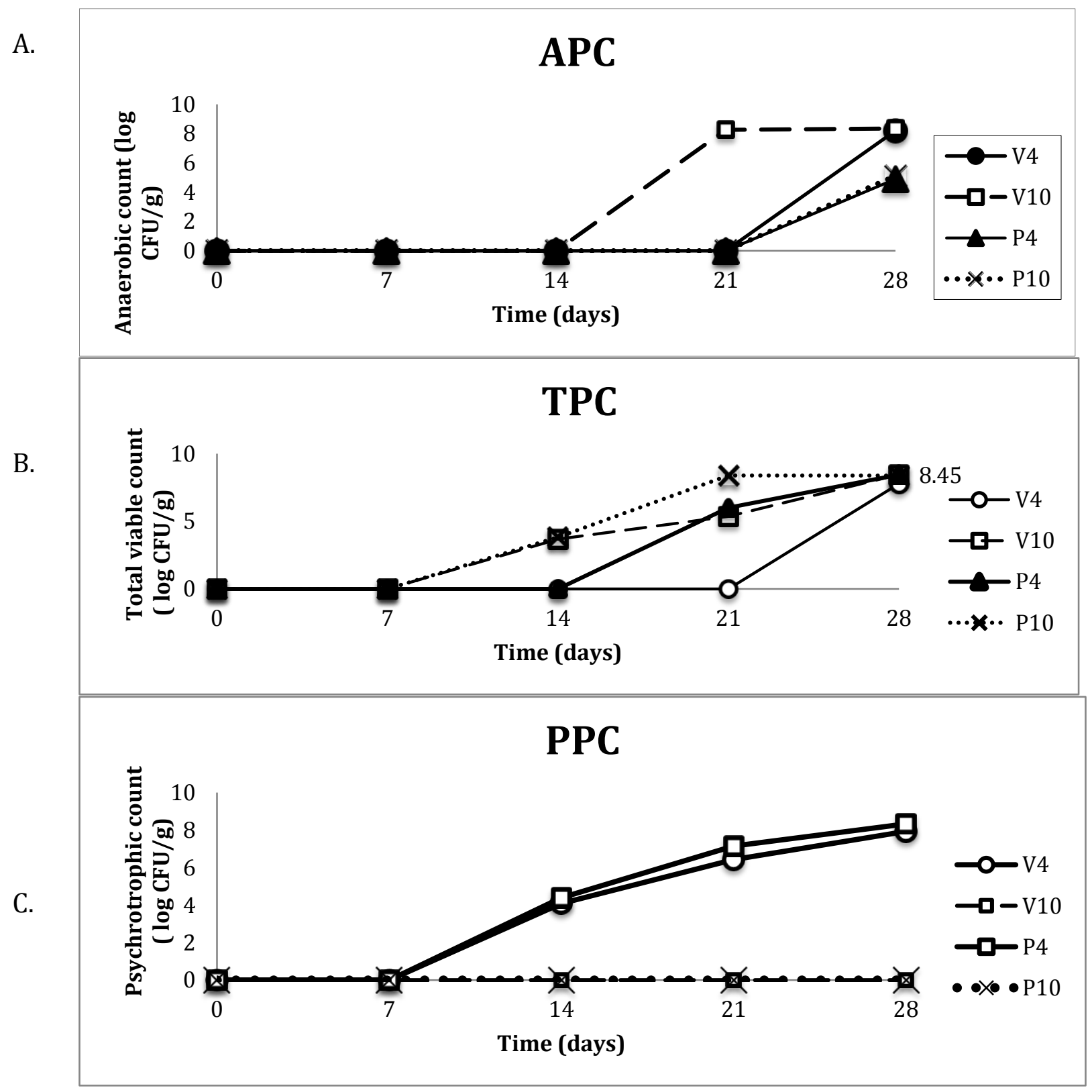

Figure 1.

Microbiological analysis of cooked $\omega-3$ egg stick gels packaged under vacuum or aerobic wrap at $4^{\circ} \mathrm{C}$ and $10^{\circ} \mathrm{C}$ over a 28 day storage period. A) Total Plate Count (TPC), B) Anaerobic Plate Count (APC), C) Psychrotrophic Plate Count (PPC). Results are recorded as means $(n=3)$ in $C F U / g$. 


\section{Table 5}

Proximate composition a of cooked $\omega-3$ egg stick packaged under vacuum or aerobic wrap at $4{ }^{\circ} \mathrm{C}$ and $10^{\circ} \mathrm{C}$ over a 28 -day period.

\begin{tabular}{|c|c|c|c|c|c|c|}
\hline \multirow[b]{2}{*}{ Attribute } & \multirow[b]{2}{*}{ Packaging } & \multicolumn{5}{|l|}{ Days of Storage } \\
\hline & & 0 & 7 & 14 & 21 & 28 \\
\hline Ash & $\begin{array}{l}\text { Vac. } 4^{\circ} \\
\text { Vac. } 10^{\circ} \\
\text { Plastic } 4^{\circ} \\
\text { Plastic } 10^{\circ}\end{array}$ & $\begin{array}{l}1.21 \pm 0.13^{\mathrm{Bb}} \\
1.23 \pm 0.16^{\mathrm{Bb}} \\
1.89 \pm 0.45^{\mathrm{Aa}} \\
1.01 \pm 0.01^{\mathrm{Cc}}\end{array}$ & $\begin{array}{l}1.5 \pm 0.34^{\mathrm{Aa}} \\
0.89 \pm 0.06^{\mathrm{Dc}} \\
1.18 \pm 0.27^{\mathrm{Bb}} \\
0.72 \pm 0.34^{\mathrm{bd}}\end{array}$ & $\begin{array}{l}1.39 \pm 0.4^{\mathrm{Bb}} \\
1.28 \pm 0.41^{\mathrm{Bb}} \\
1.74 \pm 0.15^{\mathrm{Aa}} \\
0.86 \pm 0.67^{\mathrm{Dc}}\end{array}$ & $\begin{array}{l}1.08 \pm 0.65^{\mathrm{Cc}} \\
1.34 \pm 1.92^{\mathrm{Ba}} \\
1.28 \pm 0.6^{\mathrm{Bb}} \\
1.31 \pm 0.08^{\mathrm{Bb}}\end{array}$ & $\begin{array}{l}1.13 \pm 0.19^{\mathrm{Bc}} \\
1.33 \pm 0.52^{\mathrm{Bb}} \\
1.72 \pm 0.33^{\mathrm{Aa}} \\
1.12 \pm 0.37^{\mathrm{Bc}}\end{array}$ \\
\hline Moisture* & $\begin{array}{l}\text { Vac. } 4^{\circ} \\
\text { Vac. } 10^{\circ} \\
\text { Plastic } 4^{\circ} \\
\text { Plastic } 10^{\circ}\end{array}$ & $\begin{array}{l}75.36 \pm 0.68 \\
74.92 \pm 0.6 \\
75.09 \pm 0.57 \\
74.45 \pm 2.71\end{array}$ & $\begin{array}{l}73.64 \pm 6.65 \\
75.09 \pm 5.10 \\
74.57 \pm 8.26 \\
74.48 \pm 8.14\end{array}$ & $\begin{array}{l}70.64 \pm 0.32 \\
73.86 \pm 1.78 \\
74.22 \pm 3.14 \\
75.96 \pm 3.52 \\
\end{array}$ & $\begin{array}{l}73.72 \pm 1.71 \\
71.66 \pm 1.08 \\
73.19 \pm 0.03 \\
73.36 \pm 1.84 \\
\end{array}$ & $\begin{array}{l}70.69 \pm 0.57 \\
70.79 \pm 0.96 \\
73.86 \pm 0.39 \\
73.64 \pm 0.41 \\
\end{array}$ \\
\hline Total Fat & $\begin{array}{l}\text { Vac. } 4^{\circ} \\
\text { Vac. } 10^{\circ} \\
\text { Plastic } 4^{\circ} \\
\text { Plastic } 10^{\circ} \\
\end{array}$ & $\begin{array}{l}15.33 \pm 0.53^{\mathrm{Aa}} \\
14.36 \pm 1.74^{\mathrm{Aa}} \\
14.5 \pm 4.00^{\mathrm{Aa}} \\
14.79 \pm 2.10^{\mathrm{Aa}}\end{array}$ & $\begin{array}{l}10.49 \pm 1.4^{\mathrm{Bf}} \\
11.54 \pm 1.47^{\mathrm{De}} \\
12.39 \pm 1.13^{\mathrm{Ed}} \\
14.33 \pm 2.85^{\mathrm{Aa}}\end{array}$ & $\begin{array}{l}13.16 \pm 0.01^{\mathrm{Cc}} \\
11.01 \pm 2.92^{\mathrm{Be}} \\
11.37 \pm 0.19^{\mathrm{cD}} \\
13.32 \pm 2.16^{\mathrm{Cb}}\end{array}$ & $\begin{array}{l}14.97 \pm 2.14^{\mathrm{Aa}} \\
12.46 \pm 0.67^{\mathrm{Ed}} \\
10.01 \pm 0.47^{\mathrm{bB}} \\
13.45 \pm 4.72^{\mathrm{Cb}}\end{array}$ & $\begin{array}{l}14.94 \pm 0.11^{\mathrm{Aa}} \\
14.21 \pm 0.04^{\mathrm{Ab}} \\
13.39 \pm 0.37^{\mathrm{Cb}} \\
14.52 \pm 0.79^{\mathrm{Aa}}\end{array}$ \\
\hline Crude Protein & $\begin{array}{l}\text { Vac. } 4^{\circ} \\
\text { Vac. } 10^{\circ} \\
\text { Plastic } 4^{\circ} \\
\text { Plastic } 10^{\circ}\end{array}$ & $\begin{array}{l}11.34 \pm 0.33^{\mathrm{DEc}} \\
11.36 \pm 0.24^{\mathrm{DEc}} \\
11.28 \pm 0.02^{\mathrm{DEc}} \\
11.29 \pm 0.01^{\mathrm{DEc}}\end{array}$ & $\begin{array}{l}12.59 \pm 1.76^{\mathrm{ABCDb}} \\
10.96 \pm 0.03^{\mathrm{Ed}} \\
11.64 \pm 0.25^{\mathrm{BCDEc}} \\
12.02 \pm 0.45^{\mathrm{BCDEb}}\end{array}$ & $\begin{array}{l}11.57 \pm 0.17^{\mathrm{CDEc}} \\
13.14 \pm 0.22^{\mathrm{Aa}} \\
12.51 \pm 0.34^{\mathrm{ABCDb}} \\
11.8 \pm 0.07^{\mathrm{BCDEc}}\end{array}$ & $\begin{array}{l}12.54 \pm 0.58^{\mathrm{ABCDb}} \\
13.89 \pm 0.19^{\mathrm{Aa}} \\
12.67 \pm 0.87^{\mathrm{ABCDb}} \\
13.03 \pm 0.24^{\mathrm{ABCa}}\end{array}$ & $\begin{array}{l}13.62 \pm 0.05^{\mathrm{Aa}} \\
12.4 \pm 0.23^{\mathrm{ABCDEb}} \\
11.65 \pm 0.06^{\mathrm{BCDEc}} \\
11.19 \pm 0.1^{\mathrm{DEd}}\end{array}$ \\
\hline
\end{tabular}

Different lowercase letters within the same column indicate significant differences between treatments $(\mathrm{p}<0.05)$

determined by Tukey's HSD. Different capital letters within the same row indicate significant differences between days

$(\mathrm{p}<0.05)$ determined by Tukey's HSD.

${ }^{a}$ Values are mean score \pm SD $(n=5)$.

*Interaction was not significant $(\mathrm{p}>0.05)$. 


\section{Table 6}

Concentration $^{\text {a }}$ of ALA, EPA, and DHA, omega-6/omega-3 fatty acids ( $\left.\omega-6 / \omega-3\right)$, and unsaturated/saturated fatty acids (UFAs/SFAs) in $\omega$-3 egg sticks

\begin{tabular}{lll}
\hline Fatty acids & $\omega-3$ egg stick & Whole Egg* \\
\hline ALA & $30.16 \pm 0.79$ & $0.77 \pm 0.11$ \\
EPA & $0.70 \pm 0.06$ & $0.12 \pm 0.04$ \\
DHA & $14.74 \pm 0.69$ & $4.77 \pm 0.18$ \\
$\% \omega-3$ & $49.01 \pm 0.40$ & $5.9 \pm 0.37$ \\
UFAs/SFAs & $0.45 \pm 0.01$ & $1.81 \pm 0.02$ \\
$\omega-6 / \omega-3$ & $0.31 \pm 0.01$ & $2.64 \pm 0.23$ \\
\hline
\end{tabular}

${ }^{\mathrm{a}}$ Concentrations are given as percent fatty acid in total fatty acids as mean values $\pm \operatorname{SD}(n=3)$. *Numbers taken from previous research by Kassis et al., (2010). 
Table 7

Thiobarbituric reactive substances (TBARS) test as measured by mg malondialdehyde (MDA) $/ \mathrm{kg}^{\mathrm{a}}$ sample in $\omega-3$ egg sticks packaged under vacuum or aerobic wrap at $4^{\circ} \mathrm{C}$ and $10^{\circ} \mathrm{C}$ over a 28 day storage period.

\begin{tabular}{|c|c|c|c|c|c|c|}
\hline \multirow[t]{2}{*}{ Attribute } & \multirow[t]{2}{*}{ Packaging } & \multicolumn{5}{|c|}{ Days of Storage } \\
\hline & & 0 & 7 & 14 & 21 & 28 \\
\hline \multirow[t]{4}{*}{ TBARS } & Vac. $4^{\circ}$ & $1.90 \pm 0.09^{\mathrm{DEg}}$ & $3.42 \pm 0.69^{\mathrm{BCe}}$ & $3.57 \pm 0.29^{\mathrm{BCd}}$ & $3.77 \pm 0.15^{\mathrm{BCb}}$ & $4.44 \pm 0.60^{\mathrm{ABCc}}$ \\
\hline & Vac. $10^{\circ}$ & $1.07 \pm 0.09^{\mathrm{Eh}}$ & $3.44 \pm 0.07^{\mathrm{BCe}}$ & $3.19 \pm 0.99^{\mathrm{CDf}}$ & $4.00 \pm 0.46^{\mathrm{BCc}}$ & $3.55 \pm 0.57^{\mathrm{BCd}}$ \\
\hline & Non-vac. $4^{\circ}$ & $1.05 \pm 0.16^{\mathrm{Eh}}$ & $4.80 \pm 0.04^{\mathrm{BCb}}$ & $4.40 \pm 0.08^{\mathrm{ABCc}}$ & $4.39 \pm 0.06^{\mathrm{ABCc}}$ & $5.46 \pm 0.43^{\mathrm{Aa}}$ \\
\hline & Non-vac. $10^{\circ}$ & $1.03 \pm 0.18^{E h}$ & $3.95 \pm 0.48^{\mathrm{BCc}}$ & $4.52 \pm 0.61^{\mathrm{ABCb}}$ & $5.55 \pm 0.34^{\mathrm{Aa}}$ & $5.75 \pm 0.20^{\mathrm{Aa}}$ \\
\hline
\end{tabular}

Different capital letters within the same row indicate significant differences $(\mathrm{p}<0.05)$ between treatment groups determined by Tukey's HSD. Different lowercase letters within the same column indicate significant differences $(P<0.05)$ between days

determined by Tukey's HSD.

${ }^{a}$ Values are mean score $\pm \operatorname{SD}(n=3)$ 